\title{
EFEITO DO RESÍDUO DO ABACAXIZEIRO NO NÍVEL DE COLESTEROL SANGÜÍNEO E HEPÁTICO EM RATOS
}

\author{
JULIANA PIEDADE
}

Engenheiro Agrônomo

Orientadora: Prof ${ }^{\mathfrak{a}}$ Dr ${ }^{\mathrm{a}}$ SOLANGE GUIDOLIN CANNIATTI BRAZACA

Dissertação apresentada à Escola Superior de Agricultura "Luiz de Queiroz", Universidade de São Paulo, para obtenção do título de Mestre em Ciências, Área de Concentração: Ciência e Tecnologia de Alimentos.

\section{PIRACICABA}

Estado de São Paulo - Brasil

Maio - 2001 
Dados Internacionais de Catalogaçāo na Publicaçāo (CIP) DIVISÃo DE BIBLIOTECA E DOCUMENTAÇÃO - Campus "Luiz de Queiroz"/USP

Piadade, Juliana

Efeito do resíduo do abacaxizeiro no nível de colesterol sangüíneo e hepático em ratos / Juliana Piedade. - - Piracicaba, 2001.

$63 \mathrm{p}$.

Dissertação (mestrado) - - Escola Superior de Agricultura Luiz de Queiroz, 2001. Bibliografia.

1. Abacaxi 2. Colesterol 3. Fezes 4. Fibra dietética 5. Pectina 6. Rato 7. Residuo vegetal I. Título

CDD 612.397

"Permitida a cópia total ou parcial deste documento, desde que citada a fonte - 0 autor"s 
Dedico e ofereço este trabalho ao meu esposo e amigo, Carmello, e a todos os meus familiares. 


\section{AGRADECIMENTOS}

À Escola Superior de Agricultura "Luiz de Queiroz", em particular ao Departamento de Agroindústria, Alimentos e Nutrição, pela formação recebida e acolhimento dos professores e funcionários.

À Prof $\mathrm{Dr}^{\mathrm{a}}$ Solange Guidolin Canniatti Brazaca, pelo apoio, oportunidade e orientação durante a realização deste trabalho.

À técnica Maria de Lourdes Perin Storer, pelo incentivo, amizade e auxilio nas análises laboratoriais.

Às secretárias Raquel Iracema da Silva e Marcia Regina Severino Bertarelli, pela constante ajuda e amizade.

Aos Prof ${ }^{8}$ : Dr ${ }^{\mathrm{a}}$ Marilia Oetterer, $\mathrm{Dr}^{\mathrm{a}}$ Marina Vieira da Silva e Dr Jorge Horri, pelo carinho, pelos ensinamentos, pelo orgulho de terem feito parte da minha banca de qualificação, e apoio durante o curso de mestrado.

À Prof ${ }^{a} \mathrm{Dr}^{\mathrm{a}}$ Sônia Maria de S. Piedade, pelo carinho e colaboração nas análises estatísticas do experimento.

À secretária da pós-graduação Regina Lúcia de Mello Lourenço, pela compreensão, carinho e constante apoio.

Às bibliotecárias Beatriz Helena Giongo e Midian Gustinelli, pela amizade, auxílio nas correções e organização das referências bibliográficas.

À Hércules Limeira S/A, pelo fornecimento da pectina.

Á Associação dos Produtores de Abacaxi de Guaraçaí, em especial ao $\mathrm{Sr}$. Antonio Aparecido Suttini (produtor e presidente), pelo fornecimento da matéria-prima do experimento, o resíduo do abacaxizeiro.

Ao Conselho Nacional de Desenvolvimento Científico e Tecnológico (CNPq), pelo auxilio financeiro.

A todos os meus colegas da pós-graduação, pelos momentos alegres e dificeis.

A todos os meus familiares, que sempre ajudaram, mais do que eles imaginam.

A todos os que de alguma forma contribuíram nos bons momentos do mestrado. 


\section{SUMÁRIO}

$\begin{array}{lcl} & \text { Página } \\ \text { vi }\end{array}$

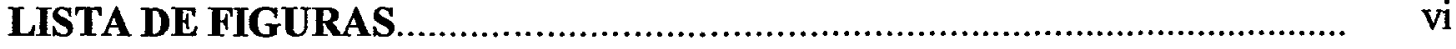

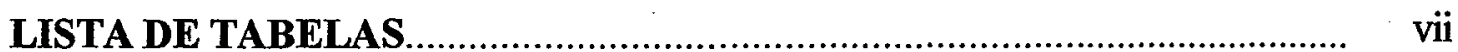

RESUMO

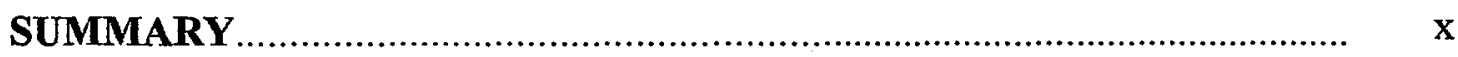

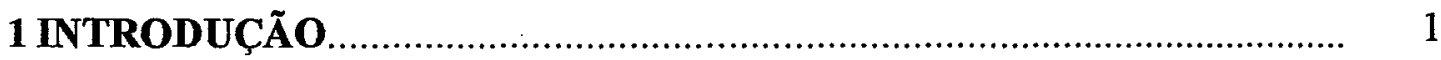

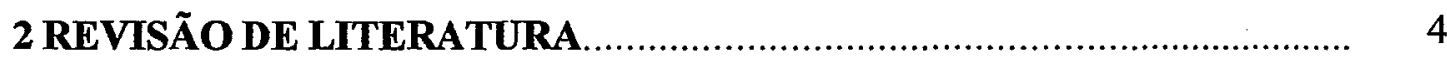

2.1 A abacaxicultura e o resíduo do abacaxizeiro.......................................... 4

2.2 As fibras na alimentação humana ............................................................ 7

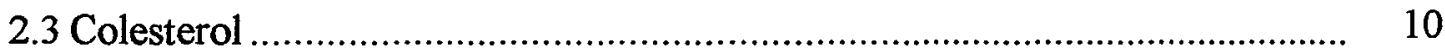

2.4 Doenças coronárias e o colesterol ..................................................... 12

2.5 Efeitos das fibras nos níveis de colesterol ............................................. 13

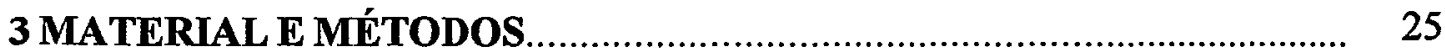

3.1 Caracterização da matéria-prima......................................................... 25

3.2 Análises químicas do resíduo do abacaxizeiro.......................................... 25

3.3 Determinação de fibra solúvel e insolúvel.............................................. 26

3.4 Ensaio biológico............................................................................... 26

3.4.1 Preparo das dietas utilizadas no ensaio biológico................................... 26

3.4.2 Animais utilizados..................................................................... 27 
Página

3.4.3 Dosagem do colesterol sangüíneo total, HDL - colesterol e LDL colesterol

3.4.4 Colesterol total no figado

3.4.5 Teor de lipídeos nas fezes ............................................................ 30

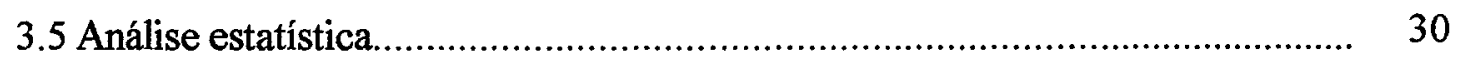

4 RESULTADOS E DISCUSSÕES................................................ 31

4.1 Caracterização do resíduo do abacaxizeiro............................................ 31

4.1.1 Composição química................................................................... 31

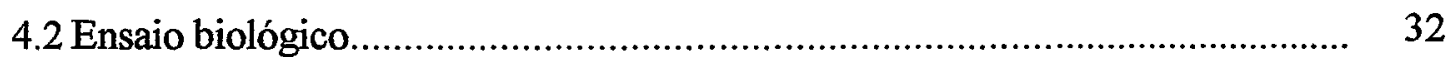

4.2.1 Consumo alimentar e ganho de peso................................................ 32

4.2.2 Colesterol total............................................................................ 35

4.2.3 HDL - colesterol........................................................................ 39

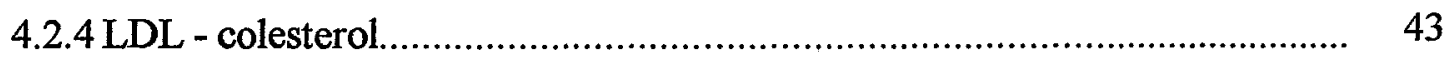

4.2.5 Colesterol total do figado ............................................................. 45

4.2.6 Teor de lipídeos nas fezes dos animais ........................................ 47

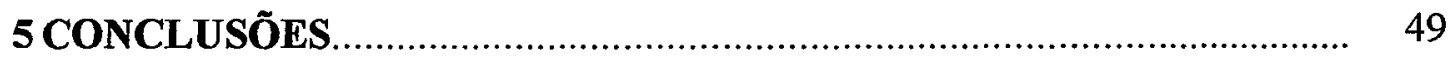

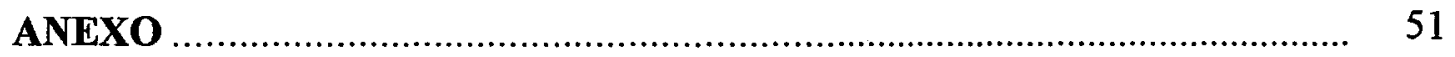

REFERÊNCIAS BIBLIOGRÁFICAS............................................ 52 


\section{LISTA DE FIGURAS}

Página

1 Consumo alimentar das dietas experimentais nos períodos de 15,30 e 45 dias......

2 Ganho de peso proporcionado pelas dietas experimentais nos períodos de ensaio de 15,30 e 45 dias.

3 Concentração plasmática de colesterol total aos $0,15,30$ e 45 dias dos animais alimentados com as dietas experimentais.

4 Concentração plasmática do HDL - colesterol aos 0, 15, 30 e 45 dias dos animais alimentados com as dietas experimentais.

5 Concentração plasmática do LDL - colesterol aos $0,15,30$ e 45 dias dos animais alimentados com as dietas experimentais. 


\section{LISTA DE TABELAS}

Página

1Composição das dietas experimentais: controle e suplementadas com o resíduo do abacaxiziero e com a pectina $(\mathrm{g} / 100 \mathrm{~g})$.

2 Porcentagem de folhas e caules do abacaxizeiro utilizados em relação ao total da planta.

3 Composição do resíduo do abacaxizeiro na matéria seca $(\mathrm{g} / 100 \mathrm{~g})$

4 Concentração plasmática do colesterol total aos 15,30 e 45 dias de duração do experimento com as dietas experimentais

5 Concentração plasmática do HDL - colesterol aos 15, 30 e 45 dias de duração do experimento com as dietas experimentais

6 Concentração plasmática do LDL - colesterol aos 15, 30 e 45 dias de duração do experimento com as dietas experimentais.

7 Concentração do colesterol total no figado dos ratos aos 15, 30 e 45 dias de duração do experimento com as dietas experimentais.

8 Teor de lipídeos das fezes dos animais, na matéria seca 


\title{
EFEITO DO RESÍDUO DO ABACAXIZEIRO NO NÍVEL DE COLESTEROL SANGÜÍNEO E HEPÁTICO EM RATOS
}

\author{
Autora: JULIANA PIEDADE
}

Orientadora: Prof ${ }^{a}$ SOLANGE GUIDOLIN CANNIATTI BRAZACA

\section{RESUMO}

A cultura do abacaxizeiro deve ser renovada para obtenção de melhores frutos. No entanto, a abacaxicultura vem enfrentando problemas, devido ao alto percentual de resíduos agrícolas (soqueiras) que se apresentam como foco de pragas e doenças para a cultura. $\mathbf{O}$ presente trabalho visou a verificar o comportamento dos animais em relação ao consumo alimentar e ao ganho de peso, a investigar o efeito da ingestão do resíduo do abacaxizeiro no nível do colesterol total, HDL - colesterol e LDL - colesterol em ratos, a medir o teor de colesterol hepático, e a quantificar os lipídeos nas fezes. Foram utilizados ratos da linhagem Wistar e uma dieta-controle com 7,5\% de banha de porco $(1,05 \%$ colesterol), a qual foi denominada hipercolesterolêmica. As dietas-testes foram feitas com diferentes níveis de resíduo do abacaxizeiro e pectina (10\%, 15\% e 25\%). As dietas do resíduo proporcionaram maior consumo alimentar quando comparadas às dietas de pectina. O maior ganho de peso foi observado nas dietas: controle e com $10 \%$ de resíduo aos 15 e 30 dias, e aos 45 dias somente a dieta-controle. O resíduo proporcionou um ganho de peso intermediário e a pectina, o menor ganho de peso. Os tratamentos com a pectina foram mais efetivos na redução do colesterol total; no entanto, aos 15 dias, as dietas com $10 \%$ e $15 \%$ de resíduo, aos 30 dias, a dieta com $10 \%$ de resíduo, e todas as dietas contendo resíduo aos 45 dias, promoveram redução no 
nível do colesterol total. A concentração plasmática do HDL - colesterol foi aumentada em quase todas as dietas, com exceção da dieta com $25 \%$ de pectina, que reduziu este nível aos 15 dias, e aos 30 dias o manteve igual ao da dieta-controle; e as dietas do resíduo que proporcionaram redução e manutenção do teor do HDL - colesterol aos 45 dias quando comparada à dieta hipercolesterolêmica. O LDL - colesterol foi reduzido em todos os tratamentos. As dietas com o resíduo promoveram diminuição desses níveis, porém em menor intensidade do que a dieta com pectina. Para o colesterol total do figado aos 15 dias, foi observado que as dietas com pectina foram mas efetivas na redução do que as dietas com o resíduo quando comparadas à dieta hipercolesterolêmica. Aos 30 dias, a melhor redução do colesterol do figado foi fornecida pelas dietas com $10 \%$ e $15 \%$ de pectina e $15 \%$ de resíduo em relação ao controle, e aos 45 dias, o colesterol total do figado foi reduzido pelas dietas com $10 \%$ e $15 \%$ de resíduo e $25 \%$ de pectina, em relação à dieta hipercolesterolêmica. Foi observado que as dietas com $15 \% \mathrm{e}$ $25 \%$ de pectina promoveram aumento da excreção de lipídeos nas fezes. 


\title{
EFFECT OF PINEAPPLE RESIDUE ON RAT BLOOD AND HEPATIC CHOLESTEROL LEVELS
}

\author{
Author: JULIANA PIEDADE \\ Adviser: Prof ${ }^{a}$ SOLANGE GUIDOLIN CANNIATTI BRAZACA
}

\section{SUMMARY}

The pineapple crop should be renewed for in order to achieve obtaining better fruits, however, the pineapple growers have faced problems due to the high amount of agricultural residues (stems and leaves) which are sources of plant pests and diseases. The present research aimed to verify the rat behavior in relation to the food intake and weight gain, to investigate the effect of pineapple residue on total cholesterol levels, HDL - cholesterol and LDL - cholesterol of rats, to measure the liver (hepatic) cholesterol and quantity of the lipids in the faeces. Wistar male rats were used and received a control-diet with $7.5 \%$ of pig lard (1.05\% cholesterol) denominated hypercholesterolemic. Test-diets were made with different levels of pineapple residue and pectin $(10 \%, 15 \%$ and $25 \%)$. Residue diets provided higher food consumption when compared to the pectin diets. The highest weight gains were observed for the following control-diets and $10 \%$ of residue at 15 and 30 days, and at 45 days only for control-diet. The residue provided intermediate weight gains and pectin the smallest weight gain. Pectin treatments were more effective in the reduction of total cholesterol; however, at 15 days, diets with $10 \%$ and $15 \%$ of residue, at 30 days diet with $10 \%$ of residue, and all residue diets at 45 days, promoted reduction of the total cholesterol level. Plasmatic concentration of $\mathrm{HDL}$ - cholesterol was increased in almost all diets, except for the diet 
with $25 \%$ of pectin, which reduced this level at 15 days, and at 30 days maintained it equal to that of the control diet. The residue diets provided both reduction and maintenance of the HDL - cholesterol levels at 45 days when compared to the hypercholesterolemic diet. LDL - cholesterol was reduced in all treatments. The residue diet decreased these levels, however in a lower intensity than the pectin diet. For the total cholesterol of the liver at 15 days the diets with pectin were observed to be more effective in reduction than the diets with residue when compared to hypercholesterolemic diet. At 30 days, the best reduction of the liver total cholesterol was observed by the diets with $10 \%$ and $15 \%$ of pectin and $15 \%$ of residue in relation to the control diet, and at 45 days, the liver total cholesterol was reduced per diets with $10 \%$ and $15 \%$ of residue and $25 \%$ of pectin in relation to the hypercholesterolemic diet. The diets with $15 \%$ and $25 \%$ of pectin were observed to promote increase in lipid excretion in the faeces. 


\section{INTRODUÇÃO}

O abacaxi é uma fruta muito apreciada nas principais regiões do mundo, não só por suas características peculiares, como também pelo reconhecimento de suas notáveis qualidades nutritivas. É uma planta originária da América tropical e subtropical, muito provavelmente do Brasil, extensivamente cultivada nos trópicos e subtrópicos de ambos os hemisférios (Montenegro,1987). No entanto, a abacaxicultura vem enfrentando graves problemas, devido ao alto percentual de resíduos agrícolas (soqueiras) que ela fornece e que se apresenta como foco de pragas e doenças da cultura (Couto, 1985).

Sabe-se que o cultivo da soqueira proporciona vários problemas que se agravam com o passar dos anos, forçando o produtor a refazer o pomar. O primeiro problema é o aumento de densidade do cultivo provocado pela substituição de cada planta por duas ou três, originárias de rebentos. $\mathrm{O}$ segundo é devido à incidência cada vez maior de pragas, como as cochonilhas, brocas ou nematóides, e de doenças como a fusariose, que concorrem para um menor rendimento e uma produção de frutos de pior qualidade. $O$ terceiro problema se relaciona à produção de frutos heterôgeneos, irregulares, pequenos, de qualidade e maturação desuniformes (Montenegro, 1987).

Resultados de estudos realizados por Py et al. (1985) mostram que a parte vegetativa, ou resíduo do abacaxizeiro, possui composição química rica em termos de carboidratos (amido, açúcares, celulose, hemicelulose), proteinas, enzimas proteolíticas (bromelinas) e fibras, que lhe conferem características de matéria-prima para a obtenção de amido, bromelinas, álcool etilico, fibras e rações animais (Carvalho et al., 1985; Ruggiero, 1982). 
Piedade \& Carvalho (1997) determinaram a composição química dos resíduos agrícolas do abacaxizeiro ( caule e folha ), os quais podem ser utilizados como matériaprima para a obtenção de pectina.

A Organização Mundial de Saúde (OMS, 1982) ressalta que a chave mestra para aumentar a expectativa de vida de uma população é a prevenção das doenças cardiovasculares. Sabe-se que níveis altos de colesterol sangǘneo, particularmente a fração LDL (low-density-lipoprotein), têm sido associados ao risco de doenças cardiovasculares, e que pequena redução do seu nível plasmático está associada ao decréscimo significativo desse risco (Anderson, 1987; Bell et al., 1990).

Muitos fatores contribuem para o desenvolvimento das doenças coronárias, principalmente a hipertensão, a hiperlipidemia e o tabagismo. Além disso, o desenvolvimento destas doenças é também afetado por diabetes melittus, obesidade, vida sedentária, tensões psicossociais, certos fatores dietéticos e, nas mulheres, a ausência de hormônios sexuais na menopausa (Anderson, 1987; Mahan \& Arlin, 1995).

O colesterol sangüíneo total e a fração LDL podem ser aumentados pela ingestão excessiva de calorias, gorduras saturadas e colesterol dietético, e possivelmente por proteína animal. Inversamente, podem ser reduzidos por diminuição do peso corporal, substituição dietética dos ácidos graxos saturados por ácidos graxos poliinsaturados, fibra alimentar solúvel (Anderson, 1987) e pelo consumo de alguns alimentos com propriedade de diminuir o colesterol, como frutas e leguminosas (Shutler \& Low, 1988).

As fibras dietéticas encontradas nos cereais também podem controlar os níveis séricos de colesterol. Porém, para que apresente algum efeito, o cereal deve conter fibras parcialmente solúveis em água (Jackson et al., 1994).

Os altos níveis de colesterol sérico, frações de colesterol e de triglicerídeos podem ser tratados, além de rigorosa dietoterapia e redução de peso corpóreo, também por exercícios fisicos. $\mathrm{O}$ uso de drogas hipolipidêmicas também tem sido recomendado nos tratamentos das hiperlipidemias. Essas drogas atuam diminuindo os níveis plasmáticos de triglicerídeos e de colesterol, e o seu sucesso depende do tipo de dieta ingerida, principalmente dos ácidos graxos, aos quais devem ser poliinsaturados em sua maioria (Penachiotti et al., 1996). 
Estudos em humanos indicam que psyllium, goma guar e pectina possuem efeito hipocolesterolêmico; farelo de aveia e soja têm efeitos intermediários, e farelo de milho, celulose e farelo de trigo não alteram significativamente os valores do colesterol sangüíneo (Anderson et al., 1990b).

A pectina é um polissacarídeo complexo, encontrado em células de várias plantas superiores. Ao contrário da celulose, dietas compostas com pectina têm se mostrado eficazes na redução dos níveis de colesterol plasmático e hepático, tanto em ratos como em humanos (Anderson et al., 1990b).

Os ratos podem ser usados como modelo para examinar a origem da fibra e seus potenciais para reduzir o colesterol sangüíneo em humanos. Vários trabalhos realizados com ratos mostram que a ingestão de fibras dietéticas solúveis em água, como a pectina e o farelo de aveia, produzem decréscimo dos níveis de colesterol sérico e hepático (Nishina \& Freedland, 1990). Esse efeito hipocolesterolêmico das fibras solúveis em água pode ser atribuído às alterações que elas provocam na absorção e no metabolismo dos nutrientes, principalmente dos lipídeos.

$O$ presente trabalho teve por objetivos verificar o comportamento dos animais com em relação ao consumo alimentar e ao ganho de peso, avaliar o efeito do resíduo do abacaxizeiro no nível do colesterol total, HDL - colesterol e LDL - colesterol em ratos, em comparação com a pectina, avaliar o efeito das dietas no nível do colesterol total do figado e analisar a excreção de lipídeos nas fezes. 


\section{REVISÃO DE LITERATURA}

\subsection{A abacaxicultura e o resíduo do abacaxizeiro}

O Brasil é o segundo maior produtor mundial de abacaxi, com 1,7 milhão de toneladas produzidas em 1999 , equivalentes a $13,24 \%$ da produção mundial, vindo depois da Tailândia e seguido das Filipinas, da Índia e da China, sendo o maior produtor da América do Sul (FAO, 1999). Entre os principais Estados brasileiros produtores estão Minas Gerais, Pará, Paraíba, Bahia, São Paulo e Rio Grande do Norte (ANUÁRIO ESTATÍSTICO DO BRASIL, 1998).

A produção brasileira é quase toda destinada ao mercado interno, em que predomina o consumo do produto "in natura", sendo que o restante é destinado à indústria para produção de suco e compotas, e apenas uma pequena parcela da produção é destinada à exportação "in natura" (Botrel \& Abreu, 1985). Da sua planta, além da bromelina, enzima proteolítica usada na indústria alimentícia e farmacêutica, podem-se extrair fibras para tecidos.

Diferentes variedades são plantadas nas regiões produtoras de abacaxi no mundo. As principais são Smooth Cayenne (com cerca de $70 \%$ da produção mundial), Pérola, Perolera, Espanhola Roja (Red Spanish), Natal Queen, Manzana, Kew e Cabezona (Cunha et al., 1994).

No Brasil, as principais variedades cultivadas comercialmente são Pérola e Smooth Cayenne. Podem ser encontradas ainda no Nordeste outras variedades de menor significado econômico, entre as quais a denominada Jupi (Medina et al., 1978).

Os frutos, da variedade Smooth Cayenne, têm formato cilindrico, coroa pequena, o peso varia de $1,5 \mathrm{~kg}$ a $2,0 \mathrm{~kg}$, a casca possui coloração alaranjada, a polpa tem cor 
amarela, rica em açúcares e de acidez moderada, é adequada à industrialização e à exportação "in natura" (Cabral, 1985; Cunha et al., 1994).

A fusariose é uma doença que vem causando grandes problemas para a cultura do abacaxi no Brasil, provocada pelo fungo Fusarium moniliforme var. subglutinans. Este fungo se manifesta em todas as partes da planta (raízes, talo, folhas e frutos), provocando a exsudação de uma substância gomosa na região afetada (Cunha et al., 1994).

A cochonilha Dysmicoccus brevipes é um dos principais insetos da cultura, sendo responsável pela transmissão da murcha do abacaxi (Reis, 1981). Ao sugar a seiva, as cochonilhas introduzem na planta agentes de natureza virótica (Gunasinghe \& German, 1989), e injetam uma toxina que causa a murcha do abacaxi, cujos sintomas característicos são vermelhão, amarelecimento e seca das pontas das folhas, que também podem se dobrar para baixo. As colchonilhas vivem nas axilas, nas folhas, nas raizes e nos frutos.

O abacaxi é considerado um dos frutos de melhor qualidade, sabor e aroma, obtendo boa aceitação por parte dos consumidores, o que fez com que sua tecnologia de produção fosse acentuadamente melhorada (Estanislau, 1985).

Ademais, a prática de utilização de plantações velhas e abandonadas como pasto, antes do estabelecimento de um novo ciclo de cultura, não é recomendada pois constitui focos de sérias pragas e doenças do abacaxizeiro, e sua destruição não permite retorno financeiro ao produtor; a prática de incorporação ao solo por gradagem seria uma opção de aproveitamento, mantendo a fertilidade do solo.

O potencial deste resíduo da cultura na alimentação para bovinos é evidenciado pelo bom teor de proteína bruta $(7,5 \%)$ e digestibilidade "in vitro" na matéria seca de $65,92 \%$, um teor maior que os $45,17 \%$ da Brachiaria decumbens com 3,5\% de proteína bruta (Oliveira \& Couto, 1985).

O Estado de São Paulo é o quinto produtor nacional, com 50.815 t., numa área plantada de $2.818 \mathrm{ha}$, obtendo rendimento médio de $18.032 \mathrm{~kg} / \mathrm{ha}$. (ANUÁRIO ESTATÍSTICO DO BRASIL, 1998). 
Apesar desta representativa produção, a grande massa que resta de um abacaxizal após a colheita do fruto, composta de folhas, caules e rebentos, corresponde a 77,5\% do total da planta, e não tem sido devidamente aproveitado, resultando em perdas econômicas (Carvalho et al., 1985). Em trabalho realizado por Couto (1985), utilizando plantas da cultivar Smooth Cayenne, com densidade de 28.000 plantas/ha e avaliadas aos três meses após a colheita dos frutos e depois da retirada das mudas, observou-se que 1 hectare de abacaxizeiro produziu 15,4 $\mathrm{t}$ de matéria seca (caules + folhas). Hiroce et al. (1977) obtiveram, para esta mesma cultivar, valores de $15,5 \mathrm{t} / \mathrm{ha}$ e $83,3 \mathrm{t} / \mathrm{ha}$ de soqueira seca e fresca, respectivamente. Este valor é muito próximo ao encontrado por Couto (1985). Se a área plantada em São Paulo em 1998 foi de 2.818ha, verifica-se que têm-se 43.397 toneladas de material considerado resíduo agrícola, ou seja, soqueira seca (caules, folhas e raízes) sem utilização.

Estes resíduos apresentam teores representativos de carboidratos, proteínas, pectinas e enzimas proteolíticas (bromelina) que possibilitam sua utilização nas indústrias de alimentos, ração animal, farmacêutica e têxtil (Oliveira \& Couto, 1985; Costa, 1987; Piedade \& Carvalho, 1997), e constituem excelente material de alimentação do gado vacum, que muito $o$ aprecia.

Trabalhos realizados por Marzola \& Bartholomew (1975) e Carvalho et al. (1985) demonstraram que a parte vegetativa e particularmente o caule do abacaxizeiro apresentam teores de amido/ha elevados, próximos ou superiores aos da mandioca. Carvalho et al. (1985), estudando 17 cultivares de abacaxi, demonstraram que caules das cultivares Smooth Cayenne e Cayenne Espinhoso sobressaíram com altos teores de amido, próximos a $20 \%$.

Carvalho et al. (1989) concluíram que os melhores períodos de desenvolvimento do abacaxizeiro para obtenção de caules e folhas com os mais altos teores de carboidratos são diferentes. Os caules se apresentaram com maiores rendimentos em amido e açúcares totais aos dois e quatro meses, e as folhas, aos quatro meses após a colheita; os teores de amido e açúcares totais dos caules e folhas decresceram no período correspondente ao amadurecimento dos frutos, e aumentaram até níveis máximos aos dois e quatro meses após a retirada dos frutos. As tendências de variações dos teores de 
amido e açúcares totais foram semelhantes em caules e folhas provenientes de mudas tradicionais e de viveiro.

Ao contrário do caule, as folhas do abacaxizeiro se apresentaram com teores baixos de amido, teores de proteínas superiores a $5 \%$ e porcentagem de celulose e hemicelulose superior a $20 \%$ (base seca), com características mais apropriadas à obtenção de rações e fibra. Devido ao teor de fibra de alta resistência apresentado pelas bromeliáceas, as folhas de algumas espécies já vêm sendo utilizadas para obtenção de cordas e outros produtos artesanais, em substituição à juta (Carvalho, 1985).

Sabendo-se do potencial do resíduo do abacaxizeiro, Piedade \& Carvalho (1997) determinaram as seguintes concentrações de pectina total e solúvel para as folhas: $4,95 \%$ e $1,75 \%$, respectivamente, e, para os caules, $5,33 \%$ e $2,35 \%$, respectivamente, na matéria integral, composição esta que tem potencial para utilização como fonte de fibras.

\subsection{As fibras na alimentação humana}

Trowell (1975) inicialmente definiu fibras dietéticas, como todos os polissacarídeos e a lignina da dieta, que não são digeridas pelas secreções endógenas do trato digestivo humano. Mais tarde, Trowell et al. (1976) concluíram que algumas fibras podem ser parcial ou totalmente hidrolisadas por bactérias ceco-colônicas. Essas bactérias utilizam energia de fontes monossacarídeas para realizar a degradação das fibras dietéticas (Selvendran \& Verne, 1990).

Atualmente, sabe-se que as fibras dietéticas e a estrutura dos polissacarídeos são fisico-quimicamente mais complexas do que se imaginava. A definição original de fibras foi assim modificada com a inclusão do termo fibra dietética total, que inclui as porções solúvel e insolúvel, e também em função do que ocorre no trato gastrointestinal. $\mathrm{O}$ método de análise e o processo de extração exercem grande influencia nas quantidades da porção solúvel e insolúvel encontradas nos alimentos (Marlett, 1990).

Experimentos com animais, principalmente com ratos, têm permitido conclusões de que: a) a adição de certas fibras à dieta é acompanhada de significativas reduções na concentração de colesterol sérico total (Kay, 1980); b) frações insolúveis da fibra 
(celulose, algumas hemiceluloses) têm muito pouca influência nos níveis de colesterol sérico total (Arvanitakis et al., 1977); c) frações solúveis (pectinas, gomas, mucilagens e algumas hemiceluloses) exercem significativo efeito hipocolesterolêmico (Anderson \& Tietyen-Clarck, 1986; Judd \& Truswell, 1985); d) reduções nos níveis de colesterol sérico são acompanhadas por decréscimo do conteúdo de colesterol no figado, na aorta e em outros tecidos (Chen et al., 1981; Judd \& Truswell, 1985; Story et al., 1981); e) maior decréscimo do colesterol é observado na fração LDL; quanto a fração HDL, não há consenso entre os autores (Bobek \& Chorvathva, 1984; Chen et al., 1981; Koo \& Stanton, 1981 e Schneeman et al., 1984).

A não-eficácia da fibra insolúvel e a eficácia da fibra solúvel em diminuir os niveis de colesterol sérico têm sido confirmadas em humanos. Os experimentos não são diretamente comparáveis, em razão do uso de diferentes quantidades, bem como de tipos de fibra, mas algumas conclusões possíveis de serem sumarizadas são as seguintes: a) fração solúvel, incluindo pectina (Jenkins et al., 1975), goma guar (Jenkins et al., 1976) e polissacarídeos de leguminosas (Mathur et al., 1968), é apontada como eficaz em reduzir moderadamente os níveis de colesterol sérico, particularmente quando os indivíduos possuem uma hipercolesterolemia na fase inicial; b) o decréscimo do colesterol sérico total observado com a fibra solúvel é devido ao decréscimo, principalmente, da fração LDL (Anderson et al., 1984); c) as frações insolúveis não são efetivas em diminuir os níveis de colesterol, mas tendem a aumentar os níveis de HDLcolesterol (Truswell \& Kay, 1975).

Segundo Selvendran \& Verne (1990), os principais componentes das fibras dietéticas são os polissacarídeos complexos, alguns associados com polifenóis (incluindo lignina) e proteína. A característica de solubilidade dos polímeros determina os efeitos fisiológicos e influencia a sua degradação pelas bactérias colônicas. As fibras com baixos níveis de ésteres de ácido ferúlico são totalmente degradadas pelas bactérias do cólon. Já os polímeros fortemente ligados (especialmente os ácidos de arabinoxilanas) e a celulose em tecidos lignificados são mais resistentes a essa degradação. 
Ainda não existe um ADI (Ingestão diária aceitável) específico para as fibras dietéticas. Segundo Al-Shoshan (1992), para indivíduos adultos, a ingestão diária de $20 \mathrm{~g}$ a $35 \mathrm{~g}$ é essencial para o funcionamento normal do intestino e para a prevenção de certas doenças, como constipação e diverticulites no cólon. As dietas vegetarianas estritas, as moderadamente ricas em fibras e as dietas ocidentais contêm, em média, respectivamente, $60 \mathrm{~g}, 35 \mathrm{~g}$ e $20 \mathrm{~g}$ de fibras. A ingestão excessiva de fibras dietéticas pode interferir no metabolismo e na absorção de oligoelementos, indispensáveis ao metabolismo de macronutrientes, e ainda provocar distúrbios abdominais, flatulência e diarréia.

A introdução de fibras dietéticas na alimentação dos indivíduos deve ser feita de forma gradual, pois o organismo humano necessita de algum tempo para se adaptar. Além disso, o efeito da ingestão das fibras somente é verificado após a fase de adaptação (Anderson et al., 1990a).

As fibras possuem diversos efeitos sobre o sistema digestivo. Uma alimentação mais rica em fibras requer maior mastigação, o que estimula o fluxo de saliva. Esse mecanismo afeta diretamente o hipotálamo, produzindo a sensação de saciedade. Também ocorrem mudanças significativas nos níveis séricos de insulina, glucagon e outros hormônios pancreáticos e gastrointestinais que são sensiveis à insulina. A insulina age como chave para a regulação hormonal, tanto para o catabolismo como para o anabolismo dos lipídeos, enquanto o glucagon antagoniza esses efeitos. Estudos nessa área sugerem que os níveis de glicose sérica, insulina e glucagon afetam os níveis de colesterol hepático e a síntese de lipoproteínas (Anderson et al., 1988).

Os gëis de fibras solúveis, como goma guar ou pectina, podem alterar o metabolismo de carboidratos, alterando o esvaziamento gástrico ou reduzindo a absorção de glicose, havendo também decréscimo na glicose plasmática e na resposta à insulina. O decréscimo no nível de glicose não ocorreu, aparentemente, devido à mudança na utilização ou na produção de glicose, mas somente na sua absorção. Outro possivel mecanismo para efeito sobre o metabolismo de glicose é o decréscimo na produção de glicose hepática. Ácidos graxos de cadeia curta produzidos por fermentação bacteriana da fibra podem ser absorvidos e diminuir a glicogênese no figado. Insulina tem sido 
reportada como eficaz em aumentar a síntese de colesterol e a síntese hepática, bem como a secre⿻̧ão de lipoproteínas de baixa densidade. Entretanto, se as fibras reduzem a absorção de carboidratos e a secreção de insulina, então elas podem ter efeito indireto sobre a síntese de lipídeos no figado (Angelis, 1993).

Muitos desses relatos indicaram que fibras solúveis em água têm importante potencial em diminuir o colesterol e deveriam ser recomendadas no controle dietético da hipercolesterolemia. Enquanto uma dieta restrita em lipídeos e colesterol pode diminuir as concentrações de colesterol sérico em 5 a 10\%, o uso adicional de alimentos ricos em fibra solúvel, como farelo de aveia e produtos de feijão, pode promover uma diminuição de $20 \%$ a $30 \%$, devendo, portanto, ser incluídos em dietas de pacientes com hipercolesterolemia (Anderson, 1987).

\subsection{Colesterol}

Cerca de $80 \%$ dos éster de colesterol são convertidos em ácidos biliares, responsáveis pela emulsão dos lipídeos no processo de absorção. No plasma sangüíneo, está na forma livre ou esterificada com ácidos graxos. Tanto os ácidos biliares como o colesterol são reabsorvidos no íleo terminal e no intestino grosso, voltando para o figado, onde novamente são excretados pela bile (Kritchevski \& Story, 1974).

Segundo Anderson et al. (1988), no caso de dietas pobres ou sem colesterol, como dos vegetarianos puros, este é sintetizado principalmente pelo figado, conforme a necessidade do organismo.

O fato de o colesterol ser absorvido somente pela solubilização do meio micelar pode explicar a baixa absorção de colesterol exógeno em individuos saudáveis, mas não explica o porquê de o colesterol endógeno ser, também, pobremente reabsorvido. Linscheer \& Vergroesen (1994) sugeriram que a absorção intestinal de colesterol é maior quando o $\mathrm{pH}$ do duodeno e jejuno proximal está reduzido do que quando este está aumentado na parte distal; assim, o aumento do $\mathrm{pH}$ pode ser um fator contribuinte para a má absorção de colesterol no intestino delgado distal. 
Diversos fatores metabólicos podem causar decréscimo real ou aparente da absorção de colesterol. Grundy \& Denke (1990) descreveram alguns desses fatores metabólicos, como: baixa quantidade de ácidos biliares; aumento da velocidade do trânsito intestinal, com decréscimo no tempo disponivel para a absorção; redução na secreção da lipase pancreática, retirando assim o colesterol da fase micelar; deficiência na capacidade da mucosa intestinal em esterificar o colesterol; e competição para absorção do colesterol biliar com o colesterol exógeno.

Segundo Mahan \& Arlin (1995), as lipoproteínas séricas são: a) quilomícrons (constituídos de triglicerídeos absorvidos na dieta); b)VLDL (lipoproteínas de muito baixa densidade, compostas por triglicerídeos, colesterol e apoproteínas); c) LDL (lipoproteínas de baixa densidade, que carregam $2 / 3$ do colesterol sérico total) e d) HDL (lipoproteínas de alta densidade).

A principal via de degradação do colesterol é sua transformação em sais biliares, ocorrendo esse processo exclusivamente no figado (Santos \& Santos, 1989), o qual produz aproximadamente $1 / 3$ do colesterol diário. A primeira etapa para a conversão do colesterol em ácidos biliares primários, cólico e quenodeoxicólico é a formação da $7-\alpha-$ hidroxicolesterol, sob a influência da enzima limitante 7- $\alpha$-hidroxilase (Grundy, 1978).

$\mathrm{O}$ colesterol, em associação com os aminoácidos taurina e glicina, forma os ácidos biliares primários ou conjugados. No intestino, por ação de bactérias, formam-se os ácidos biliares secundárioș. Segundo Moundras et al. (1994), esses compostos podem ser reabsorvidos ou então excretados na presença de fibras dietéticas. As fibras produzem um complexo com os ácidos biliares no lúmem intestinal, reduzindo a atividade de reabsorção no intestino delgado, causando maior excreção fecal.

Os ácidos biliares, retornam ao figado, inibem a sintese hepática de novos ácidos biliares. Qualquer substância que diminua a reabsorção dos ácidos biliares promoverá maior conversão de colesterol hepático em ácidos biliares. Acredita-se que a fração solúvel da fibra dietética possa desempenhar essa função (Santos \& Santos, 1989). 


\subsection{Doenças coronárias e o colesterol}

A relação entre o colesterol plasmático $\mathrm{e}$ as doenças coronárias foi observada $\mathrm{e}$ comprovada através de estudos que concluíram: a) o colesterol é um componente importante da placa de ateroma; b) a hipercolesterolemia, adquirida pela dieta ou de forma genética, leva à aterosclerose; c) níveis plásmáticos de colesterol estão diretamente correlacionados à prevalência de doenças coronárias e à gravidade da aterosclerose e d) a capacidade das lipoproteínas de transportar colesterol até a parede arterial interfere na incidência da doença (Alves \& Gerude, 1995).

Os principais efeitos do colesterol e lipídeos são: a) alterar os níveis de colesterol sérico; b) influenciar na agregação de plaquetas; c) originar depósitos nas paredes das artérias (Anderson et al., 1988).

Segundo Grundy \& Denke (1990), as doenças coronárias continuam sendo causas importantes de morte no mundo ocidental. A concentração do colesterol plasmático, a distribuição dos lipídeos corpóreos e as dietas ricas em ácidos graxos saturados são reconhecidas como as maiores causas das doenças coronárias.

Os ácidos graxos saturados encontram-se em maior quantidade nos tecidos animais, e seu aumento tem influência três vezes maior nas doenças coronárias do que o colesterol. Deve-se ressaltar que indivíduos com altos níveis de colesterol e triglicerídeos séricos são mais suscetíveis a doenças coronárias (Oliveira \& Quintão, 1992).

A concentração do colesterol plasmático é controlada por vários fatores, incluindo a entrada do colesterol dietético e a liberação das lipoproteínas na circulação, por meio de vias dependentes e independentes de receptores (Jackson et al., 1994).

As lipoproteínas no sangue são complexos hidrossolúveis com alto peso molecular e que transportam lipídeos. Esses elementos são compostos por colesterol, fosfolipídeos, triglicerídeos e proteínas, em diferentes proporções. Deve-se ressaltar que, sempre que houver altos níveis de colesterol e triglicerídeos séricos, haverá também altas concentrações de lipoproteínas (Anderson et al., 1988). 
De acordo com Alves \& Gerude (1995), as hiperlipoproteinemias são causadas por distúrbios no transporte dos lipídeos como conseqüência da síntese acelerada ou retardo na degradação das lipoproteínas transportadoras do colesterol e dos triglicerídeos do plasma.

Evidências epidemiológicas indicam que níveis elevados da fração HDLcolesterol estão inversamente associados com a incidência de doenças coronárias. A função protetora desta fração é devida ao transporte do colesterol, dos tecidos periféricos para o figado. Baixos níveis de HDL foram identificados como fatores de risco para as doenças coronárias em homens e mulheres de 49 a 82 anos. Observou-se ainda aumento dos índices das doenças quando os níveis da fração LDL - colesterol estavam elevados, e devido à formação de faixas de gordura na aorta (Anderson et al., 1988; Anderson et al., 1990b).

\subsection{Efeitos das fibras nos niveis de colesterol}

Medellin et al. (1998), realizaram estudo com nopal (Opuntia ficus indica) cru e cozido, cujos teores de fibra dietética total são de $42,80 \%$ e $41,26 \%$ na base seca. $O$ ensaio biológico teve duração de 28 dias e adição de $8 \%$ de banha de porco. As dietas comparadas foram as seguintes: I-celulose (2,5\%); II-celulose (5,0\%); III-nopal cru desidratado (6,23\%); IV- nopal cru desidratado (12,46\%); V-nopal cozido desidratado (6,03\%); VI-nopal cozido desidratado (12,06\%). O consumo alimentar dos animais não demonstrou diferença significativa em relação à dieta-controle (I), com exceção do tratamento VI, em que se observou o menor consumo alimentar, o mesmo ocorrendo para o ganho de peso dos animais. Em relação ao colesterol total e à fração HDL não houve diferença significativa entre os tratamentos. Nas frações LDL e VLDL observouse diferença significativa entre os tratamentos. $O$ controle resultou no maior valor: os tratamentos II, III, V e VI foram considerados similares, e tiveram valores de $33,81 \mathrm{mg} / \mathrm{dl}$ a $17,55 \mathrm{mg} / \mathrm{dl}$, e o tratamento IV mostrou um valor significativamente menor de $14,55 \mathrm{mg} / \mathrm{dl}$, o que indica uma redução de $34 \%$ em relação ao grupo controle. 
Alvarado et al. (1999) estudaram o efeito do resíduo industrial do tomate - RIT (pele e semente) no nível do colesterol em ratos. Este produto possui um teor de fibra dietética total de $55,1 \%$ na base seca. $O$ experimento teve duração de 18 dias, e as dietas foram acrescidas de $1 \%$ de colesterol e $0,1 \%$ de ácido cólico, sendo que a dieta-controle não possuía fibra, e as com o RIT, $13,4 \%, 26,3 \%$ e $38,7 \%$ de fibra respectivamente. Não houve diferença no ganho de peso dos animais entre os grupos experimentais. $O$ consumo alimentar tendeu a aumentar com o incremento na concentração de RIT na dieta. A concentração do colesterol total, HDL e LDL - colesterol não apresentou diferença significativa em relação à dieta- controle.

Segundo Rosa et al. (1998a), em estudo realizado com ratos machos e duração de 28 dias, foram fornecidas dietas acrescidas de $1 \%$ de colesterol e $0,1 \%$ de ácido cólico, e adicionadas com $30 \%$ de fibra proveniente do feijão preto integral e sem casca (Phaseolus vulgaris L.). $\mathrm{O}$ teor de fibra insolúvel do feijão preto integral e sem casca é de $17,17 \%$ e $12,53 \%$, e a fração solúvel de $4,67 \%$ e $4,83 \%$, respectivamente. A dieta com feijão preto integral reduziu os níveis de colesterol sangüíneo em 15\% (nãosignificativo) e a dieta com feijão preto sem casca promoveu uma redução de $35 \%$, em relação ao grupo controle (celulose + ácido cólico + colesterol). Os niveis de HDL colesterol foram reduzidos pelas duas dietas em $48 \%$ e $36 \%$, respectivamente, para a dieta de feijão preto integral e feijão preto sem casca, não havendo diferença significativa entre si. Tal redução nos níveis de HDL não é desejável, visto que essas lipoproteínas estão associadas à redução do risco de doenças cardiovasculares, em razão do seu papel no transporte reverso de colesterol e, também, da inibição da deposição de LDL nas paredes da artéria. Tanto para o consumo alimentar como para o ganho de peso não foi observada diferença significativa nessas análises entre os tratamentos. A adição de feijão não promoveu alteração na deposição de lipídeos e de colesterol no figado dos animais alimentados com dieta de colesterol e ácido cólico, mas pode reduzir a deposição de outros compostos, como água, proteína e glicogênio, resultando em menor peso do figado. Não houve diferença significativa entre as dietas para a excreção fecal de lipídeos. 
Em trabalho visando a investigar os efeitos do feijão (Phaseolus vulgaris L.) preto, carioquinha e vermelho, os quais apresentaram $17,31 \%, 17,18 \%$ e $20,39 \%$ de fibra insolúvel e $5,77 \%, 6,18 \%$ e $5,95 \%$ da solúvel, respectivamente, na redução do colesterol sangüíneo em ratos, Rosa et al. (1998b) forneceram aos animais dietas acrescidas de 1\% de colesterol e $30 \%$ de feijão preto, carioquinha e vermelho por um período de 28 dias. Os resultados observados foram que as dietas de feijão reduziram os níveis de colesterol sangüíneo, porém não houve diferença significativa, sendo que o feijão preto reduziu em $16 \%$, o vermelho, $12 \%$ e o carioquinha, $11 \%$, em relação ao grupo controle. Não houve diferença significativa entre os grupos experimentais quanto ao ganho de peso e consumo alimentar.

Friedman et al. (2000) estudaram o efeito do tomate verde e maduro no nivel de colesterol em hamster. $O$ tomate verde apresentou um teor de $19,76 \%$ de fibra insolúvel e $4,26 \%$ de fibra solúvel, e os tomates maduros apresentaram $17,03 \%$ e $4,91 \%$, respectivamente de fibra insolúvel e solúvel; do total da fibra dietética do tomate, cerca de $80 \%$ correspondem à fração insolúvel. O ensaio biológico teve duração de 21 dias, e as dietas foram acrescidas de $2 \%$ de colesterol; os teores de fibra das dietas foram $10,9 \%$ de celulose, $14,7 \%$ de tomate verde desidratado e $13,0 \%$ de tomate maduro desidratado. Os resultados mostraram redução de $59 \%$ e $44 \%$ no nível do LDL - colesterol dos animais alimentados com as dietas de tomate verde e maduro, respectivamente, em relação à dieta de celulose (controle). O VLDL - colesterol também teve redução significativa nos hamsters alimentados com as dietas de tomate, mas o HDL colesterol não teve redução significativa em relação ao controle. $O$ colesterol total foi reduzido em $27 \%$ para o verde e $23 \%$ para o maduro em relação à dieta controle. Os animais alimentados com as dietas de tomate maduro e verde tiveram um menor ganho de peso, de $12 \%$ e $20 \%$, e também um menor consumo alimentar, de $9 \%$ e $18 \%$, respectivamente, quando comparados à dieta-controle. Vários componentes do tomate podem atuar na redução no nível do LDL - colesterol. Estes incluem fibra (Kritchesvsky'1, 1988),

\footnotetext{
${ }^{1}$ KRITCHEVSKY, D. Dietary fiber. Ann. Rev. Nutr. v.8, p. 301-328, 1988.
} 
proteína (Morita et $\mathbf{a l}^{2}$., 1997), licopeno e outros antioxidantes (Anese et $\mathbf{a l}^{3} ., 1999$ ), "tomatine" (Friedman et al ${ }^{4}$., 2000), e gordura polinsaturada (USDA $\left.{ }^{5}, 1984\right)$.

O estudo de Martín-Carrón et al. (2000) teve o objetivo de avaliar o efeito de produtos de uva ricos em polifenóis e fibra dietética no nível de colesterol em ratos. $\mathbf{O}$ conteúdo de fibra dietética variou de $54 \%$ a $59 \%$ nesses produtos. O ensaio biológico teve duração de 42 dias, e as dietas eram acrescidas de 1\% de colesterol, $15 \%$ de banha e $0,2 \%$ de ácido cólico. A dieta de celulose (controle) tinha 5\% de fibra, as dietas-testes apresentavam $10 \%$ de fibra dietética proveniente de casca de uva vermelha (RGP), casca de uva branca (WGP) e sementes de uva branca (WGS). Não houve diferença significativa para o ganho de peso tanto para as dietas acrescidas de colesterol como para as livres entre os tratamentos; somente a dieta de WSG obteve o maior consumo alimentar, diferindo das demais dietas. Quando as dietas eram isentas de colesterol, o colesterol total sérico e o LDL - colesterol não tiveram diferença significativa entre os grupos alimentados com as frações da uva e a dieta-controle. O HDL - colesterol foi aumentado nas dietas com RGP e WGS, tendo diferença em relação ao controle. As dietas contendo colesterol e adicionadas com as frações da uva como fonte de fibra dietética diminuíram as concentrações do colesterol total e do LDL - colesterol, quando comparadas ao grupo controle. A maior redução no nível do colesterol total foi observado nas dietas com RGP e WGP, as quais promoveram redução de $30 \%$ e $21 \%$, respectivamente, em relação ao controle. O LDL - colesterol foi reduzido em todas as dietas, proporcionando redução de $40 \%$ não havendo diferença significativa entre si, porém diferindo da dieta-controle. A concentração do HDL - colesterol não apresentou diferença entre as dietas de RGP e a controle; no entanto, as dietas com WGP e WGS

\footnotetext{
${ }^{2}$ MORITA,T.; OH-HASHI, A.; YAKEI, K.; IKAI, M.; KASAOBA, S.; KIRIYAMA, S. Cholesterollowering effects of soybean, potato and rice proteins depend on their low methionine contents in rats fed cholesterol-free purified diet. Journal of Nutrition, v. 127, n. , p.470-477, 1997.

${ }^{3}$ ANESE, M.; MANZOCCO, L.; NICOLI, M. C.; LAURIC, C. R. Antioxidant properties of tomato juice as affected by heating. Journal of Science Food Agriculture. V.79, p. 750-754, 1999.

${ }^{4}$ FRIEDMAN, M.; FITCH, T. E.; YOKOYAMA, W. H. Lowering of plasma LDL cholesterol in hamsters by the tomato glycoalkaloid tomatine. Food Chemistry, v. 38, p. 549-553, 2000.

${ }^{5}$ USDA [U. S. Department of Agriculture]. 1984 Composition of Foods: Vegetables and Vegetable Products. Handbook 8-11 (Suplement). Washington, D. C.: Human Nutrition Information Service, USDA. p. 449458.
} 
promoveram aumento de $76 \%$ no nível do HDL - colesterol, sendo este significativo em relação à dieta-controle. Todas as dietas proporcionaram aumento na excreção de lipídeos pelas fezes; no entanto, as dietas com WGS e WGP foram as que tiveram os melhores resultados, promovendo aumento de $80 \%$ e $60 \%$ em relação ao controle. O efeito hipocolesterolêmico das frações da uva pode ser atribuído à fração polifenólica e às características da fibra (solúvel e insolúvel). $\mathrm{O}$ mecanismo envolvido não está claro, mas é possível considerar que os polifenóis podem adsorver o colesterol, ácidos biliares e os lipídeos dietéticos, aumentando sua excreção fecal (Bravo et al., 1994; Tebib et al., 1994).

- Shinnick et al. (1990) estudaram o efeito do farelo de aveia no nível de colesterol em ratos. $O$ farelo de aveia apresentou teor de fibra solúvel de $8,6 \%$ e de fibra insolúvel de $17,7 \%$ na base seca. $O$ experimento teve duração de 20 dias, e as dietas foram acrescidas de $1 \%$ de colesterol mais $0,1 \%$ de ácido cólico. A dieta-controle não obteve adição de colesterol, somente $5 \%$ de celulose; a dieta hipercolesterolêmica foi acrescida de colesterol mais $5 \%$ de celulose; e as dietas testes apresentavam de $0 \%$ a $10 \%$ de fibra dietética proveniente do farelo de aveia. $O$ consumo alimentar e ganho de peso não tiveram diferença significativa, e se mantiveram iguais em todos os tratamentos. Pode-se observar que à medida que foram aumentadas as porcentagens de fibras, os níveis do colesterol foram reduzindo, mostrando que a dieta que obteve o melhor efeito hipocolesterolêmico foi a com $10 \%$ de farelo de aveia, a qual promoveu redução de $24 \%$ e $11 \%$ no nível do colesterol total quando comparada à dieta hipercolesterolêmica e à controle. Os autores sugerem que a redução dos níveis do colesterol total pode estar relacionada com a ingestão de altos teores de fibra solúvel; no entanto, outras pesquisas citadas pelos autores sustentam que é devido à proteína vegetal $\left(\right.$ Sugano $\left.^{6}, 1983\right)$ e a componentes lipofilicos dos grãos (Qureshi et al ${ }^{7}$., 1986). Para o colesterol total do figado; observou-se que as dietas acrescidas com 0 a 3\% de fibra mantiveram o nível

\footnotetext{
${ }^{6}$ SUGANO, M. Hypocholesterolemic effect of plant protein in relation to animal protein: mechanism of action. In: Animal and Vegetable Proteins in Lipid Metabolism and Atherosclerosis (GILBNEY, M. J.; KRITCHEVSKY, D, eds), p. 57-84, Alan R. Liss, New York, NY. 1983.

${ }^{7}$ QURESHI, A. A.; BURGER, W. C.; PETERSON, D. M.; ELSON, C. E. The structure of na inibitor of cholesterol biosynthesis isolated from barley. J. Biol. Chem. V. 261, n. 10544-10550, 1986.
} 
igual ao da dieta hipercolesterolêmica; dietas com $4 \%$ a $8 \%$ de fibra promoveram redução intermediária do colesterol total do figado; e a dieta com $10 \%$ de fibra foi a que promoveu a maior redução do colesterol total do figado, de $39 \%$ em relação à dieta hipercolesterolêmica; no entanto, em relação à dieta-controle, não houve redução do colesterol do figado pelas dietas com farelo de aveia.

Pérez-Olleros et al. (1999) estudaram o efeito da fibra natural de algarroba (FNA), a qual corresponde à parte insolúvel da polpa. $\mathrm{O}$ ensaio biológico teve duração de 28 dias, e as dietas eram acrescidas de $2 \%$ de colesterol. Os teores de fibra das dietas eram de 5\% para FNA e celulose. A ausência de colesterol nas dietas não afetou significativamente a colesterolemia dos animais que ingeriram a dieta com FNA em relação ao controle (celulose). $\mathrm{O}$ nível de colesterol sangüíneo dos animais alimentados com o suplemento de colesterol, tanto para o tratamento controle que ingeriram celulose como para aqueles que ingeriram a FNA, aumentava semanalmente. No entanto, esse aumento foi sempre inferior nos animais que ingeriram FNA com o suplemento do colesterol em relação àqueles que tomaram celulose, e essas diferenças se acentuaram com o passar das semanas; na quarta semana, os animais que consumiram a dieta de celulose apresentavam colesterolemia de $235 \mathrm{mg} / \mathrm{dl}$, e os animais que consumiram a dieta de FNA obtiveram colesterolemia de $167 \mathrm{mg} / \mathrm{dl}$, a qual proporcionou redução de $29 \%$ do colesterol total sangǘneo em relação à dieta-controle. A FNA, devido à sua composição, principalmente de fibra insolúvel, fundamentalmente polifenóis dificilmente fermentáveis (Requejo et al., 1997), poderia produzir seqüestro de esteróis no intestino delgado, já que os polifenóis não são metabolizados pela microflora (Bravo et al.,1992), dificilmente podem interferir na síntese do colesterol, e portanto só podem agir no cólon impedindo a reabsorção dos esteróis ligados no intestino delgado (Gelissen \& Eastwood, 1995). Portanto, a FNA reduz os niveis séricos do colesterol somente quando os animais ingerirem dietas ricas em colesterol. A excreção fecal de lipídeos foi aumentada na dieta com FNA em $67 \%$ quando comparada à dieta-controle.

O mecanismo pelo qual as fibras dietéticas apresentam o papel protetor contra as doenças cardiovasculares parece ser pela redução do colesterol sangüíneo. Vários trabalhos com humanos e animais têm demonstrado que a pectina é o maior componente 
da fibra responsável por esta atividade, e que a suplementação de dietas com pectina é efetivo na redução dos níveis de colesterol sangüíneo (Baker, 1994).

A partir de alguns resultados obtidos com estudos em humanos, pode-se observar uma dose de resposta entre o nível de suplementação com pectina e a redução do colesterol sangüíneo. Em geral, uma adição de pectina dietética com nível inferior a $6 \mathrm{~g} /$ dia tem sido muito baixo para realizar uma redução significativa no colesterol sangǘneo. Em média, um limite efetivo pode ser alcançado com $15-20 \mathrm{~g} / \mathrm{dia}$, o qual promove uma redução de 11-12\% do nível de colesterol sangüíneo (Ginter et al., 1979).

A pectina, embora não afete as enzimas digestivas dos humanos, é completamente fermentada por bactérias residentes da flora intestinal. A fermentação da pectina pelas bactérias produz ácidos graxos de cadeia curta, primeiramente o acetato, propionato e butirato, os quais podem ser utilizados pelas bactérias ou absorvidos pela mucosa intestinal (Chen et al., 1984; Cummings, 1981). Até mesmo com a ingestão de $30 \mathrm{~g} /$ dia de pectina, os resíduos do ácido galacturônico não puderam ser detectados nas fezes. Assim uma moderada adição de pectina geralmente resulta em pequena ou nenhuma massa fecal (Ross \& Leklem, 1981; Stasse-Wolthius et al., 1980).

Vários estudos têm demostrado que a suplementação dietética com pectina aumenta a excreção fecal de gordura, esteróis e ácidos biliares (Kay \& Truswell, 1977; Miettinen \& Tarpila, 1977).

Aumentada a excreção dos ácidos biliares interrompe a circulação enterohepática, causando aumento nas funções do figado para a síntese do ácido biliar a partir do colesterol (Fernandez et al., 1990). Isto tem sido demonstrado em ratos que foram alimentados com pectina, que promoveu aumento hepático significativo, com a atividade da CoA-redutase 3-hidroxi-metilglutaril, sendo esta uma enzima chave para a síntese do esterol (Nishina et al., 1991). Dessa maneira, a perda dos ácidos biliares serviu para reduzir o "pool" do colesterol circulante.

Estudos "in vitro" têm mostrado que a pectina reduz a atividade da enzima pancreática, a qual poderia aumentar a excreção de gorduras pelas fezes (Dutta \& Hlasko, 1985). Ullrich (1987) tem questionado o retardo na absorção dos carboidratos e a redução na resposta da insulina, o que poderia diminuir a síntese hepática dos lipídeos. 
A redução no nivel do colesterol sangüíneo pode ser prejudicial se esta redução for muito grande na fração HDL do colesterol, pois pode estar associada com o aumento no risco das doenças cardiovasculares (Reiser, 1987).

Embora Koo \& Stanton (1981) tenham notado uma diminuição no HDLcolesterol em ratos alimentados com pectina, outros (Chen et al., 1981) observaram que a pectina dietética aumentou o HDL-colesterol nessa espécie. Em humanos, o colesterol total sangüineo teve redução a partir da suplementação com pectina, sem reduzir os niveis do HDL-colesterol (Jenkins et al., 1979; Nakamura et al., 1982; Stasse-Wolthius et al, 1980). Em dois estudos, a diminuição do colesterol sangüíneo foi diretamente atribuído ao declínio do LDL-colesterol (Durrington et al., 1976; Nakamura et al., 1982).

Arjmandi et al. (1992a), em ensaio biológico com ratos, utilizaram dietas com $10 \%$ de psyllium e farelo de aveia. Os resultados demonstraram que não houve diferença significativa em comparação aos ratos alimentados com a dieta-controle de celulose. $\mathrm{O}$ ganho de peso na dieta de $10 \%$ de pectina e duração de 21 dias teve uma redução de $7,3 \%$, sendo significativa quando comparado com os outros grupos. Igualmente, os ratos alimentados com a pectina tiveram uma redução de $17,3 \%$ na ingestão alimentar quando comparado aos demais grupos. Quando as dietas foram suplementadas com $0,3 \%$ de colesterol, causaram um ligeiro aumento na concentração plasmática do colesterol total, porém não-significativo para todos os animais. Quando os ratos foram alimentados com a dieta de $10 \%$ de pectina e duração de 21 dias, houve redução de $25,3 \%$ no colesterol do plasma quando comparado à dieta de celulose. Entre os ratos alimentados com $0,3 \%$ de colesterol, o colesterol total do figado apresentou redução significativa nos grupos alimentados com pectina e psyllium comparados aos alimentados com celulose; promovendo redução de $54 \%$ e $40 \%$, quando comparados à dieta-controle; essa redução pode ter ocorrido devido a uma supressão na absorção do colesterol dietético. No entanto, a dieta acrescida de farelo de aveia promoveu aumento do colesterol total do figado de $17 \%$ em relação ao controle. Estes resultados concordam com aqueles de Kritchevsky et al. (1984), que demonstraram significativo aumento na concentração do colesterol total do figado em ratos alimentados com dietas suplementadas com $10 \%$ de farelo de aveia e $0,5 \%$ de colesterol do que os alimentados com celulose. Na ausência do 
colesterol dietético, somente a dieta com $10 \%$ de pectina reduziu o nível do colesterol do figado; as demais dietas mantiveram esse nível igual ao da dieta-controle.

Dietas contendo pectina com ou sem colesterol dietético têm uma grande influência nos lipídeos do figado, colesterol do figado e no colesterol total plasmático. Similarmente, Chen et al. (1981) apresentaram redução significativa dos lipídeos do figado, colesterol do figado e nas concentrações plasmáticas do colesterol em ratos alimentados com $10 \%$ de pectina e $1 \%$ de colesterol, quando comparados com ratos alimentados com $10 \%$ de celulose.

Segundo Arjmandi et al. (1992b), ratos tratados com uma dieta com 7,5\% de pectina, e duração de 21 dias, tiveram uma redução de $13,0 \%$ no consumo alimentar quando comparados ao grupo alimentado com celulose. Esse baixo consumo alimentar foi refletido no menor ganho de peso final para estes animais, que foi de $9,6 \% \mathrm{em}$ relação à dieta de celulose. As dietas suplementadas com $0,3 \%$ de colesterol promoveram ligeiro aumento na concentração plasmática do colesterol total, porém nãosignificativo. Quando os ratos foram alimentados com a dieta de 7,5\% de pectina e duração de 21 dias, houve redução de $20,2 \%$ no colesterol do plasma quando comparado à dieta-controle. Quando as dietas não eram acrescidas de colesterol, o colesterol do figado se manteve igual para todas as dietas. Com a adição de $0,3 \%$ de colesterol, todas as dietas reduziram o colesterol total do figado quando comparadas à dieta de celulose (controle), promovendo redução de $68 \%, 56 \%$ e $35 \%$, respectivamente para as dietas adicionadas com 7,5\% de pectina, psyllium e farelo de aveia.

Em estudo realizado por Anderson et al. (1994), em que as dietas fornecidas aos animais continham $6 \%$ de fibra, $1 \%$ de colesterol, $0,2 \%$ de ácido cólico e duração de 21 dias, verificou-se diferença significativa no ganho de peso entre os grupos. $O$ ganho de peso foi similar nos ratos alimentados com a dieta basal (sem colesterol) e a dietacontrole (celulose). Os ratos alimentados com o farelo de milho tiveram os maiores ganhos de peso, que significativamente excederam os ganhos de peso dos ratos alimentados com as dietas basal, goma guar, farelo de aveia, goma de aveia, psyllium, farelo de arroz e farelo de trigo. Os ratos alimentados com o farelo de arroz foram os que tiveram o menor ganho de peso quando comparados aos alimentados com as demais 
dietas. A concentração média do colesterol foi de $89,94 \mathrm{mg} / \mathrm{dl}$ para os ratos alimentados com dieta basal, e foi significativamente menor do que os valores das demais dietas, com exceção da dieta com $6 \%$ de psyllium e duração de 21 dias. A concentração média do colesterol plasmático foi de $169,84 \mathrm{mg} / \mathrm{dl}$ quando o ácido cólico $(0,2 \%)$ e o colesterol (1\%) foram adicionados à dieta basal. Os ratos alimentados com a dieta de $6 \%$ de psyllium tiveram a menor concentração plasmática do colesterol, que foi de $111,94 \mathrm{mg} / \mathrm{dl}$, promovendo redução de $34 \%$ do colesterol plasmático em relação à dietacontrole (celulose). A dieta acrescida de $6 \%$ de pectina promoveu redução no colesterol plasmático de $18 \%$ em comparação à dieta de celulose; as dietas de farelo de aveia e fibra de soja reduziram o colesterol, respectivamente em $7 \%$ e $11 \%$. O farelo de arroz e o farelo de milho demonstraram aumento nos níveis séricos do colesterol total de $9 \%$ e $7 \%$ em comparação à dieta-controle. As concentrações de colesterol no figado diferiram significativamente entre os grupos. Valores oito vezes maiores foram encontrados nos ratos alimentados com a dieta de celulose (controle) quando comparados à dieta basal. Os ratos alimentados com goma guar, farelo de aveia, goma de aveia, pectina, psyllium e fibra de soja tiveram significativa redução no nível do colesterol do figado quando comparados à dieta-controle. A pectina, a fibra de soja e o farelo de aveia forneceram redução de $25 \%, 19 \%$ e $19 \%$, respectivamente, da concentração do colesterol total do figado quando comparadas à dieta de celulose.

Os resultados observados por Yamada et al. (1999) indicam que os animais alimentados com dietas com fibra solúvel reduziram o colesterol total sangüíneo quando comparado à dieta de celulose. No entanto, não houve diferença significativa na redução do colesterol total entre as dietas com 5\% de goma guar hidrolizada, $5 \%$ de goma guar, $5 \%$ de glucamana e $5 \%$ de pectina de alta metoxilação, sendo que a pectina proporcionou redução nos níveis séricos do colesterol total de $26,0 \%$ em relação à dietacontrole. $\mathrm{O}$ ganho de peso dos animais não obteve diferença significativa entre todas as dietas: os animais ganharam em média $153 \mathrm{~g}$ em todo o experimento que teve a duração de 3 semanas. A ingestão alimentar dos animais também não demonstrou diferença significativa entre as dietas: a ingestão média diária dos animais foi de $18 \mathrm{~g}$. 
Segundo Al-Othman et al. (1998), os grupos alimentados com 1\% de colesterol e duração de 35 dias apresentaram um nível do colesterol total significativamente menor na dieta acrescida de $7,5 \%$ de goma arábica do que a de celulose. A dieta de 7,5\% goma arábica proporcionou aumento do HDL - colesterol quando comparada à dieta de celulose, ambas acrescidas de $1 \%$ de colesterol, porém não reduziu o LDL - colesterol quando comparada à dieta de celulose. Não houve diferença significativa entre as dietas para ganho de peso e consumo alimentar.

Jimenez-Vergara et al. (1999), em seu trabalho, observaram que porcos-da-índia alimentados com as dietas de celulose, pectina e psyllium não tiveram diferença significativa entre os tratamentos para o ganho de peso. O ensaio teve duração de 28 dias, e os resultados permitem dizer que o nível de colesterol total sangüíneo foi reduzido em $36 \%$ e $66 \%$, respectivamente para as dietas com pectina e psyllium em relação ao controle. O LDL - colesterol teve redução de $37 \%$ e $64 \%$ para as dietas com pectina e psyllium, tendo diferença significativa em comparação à dieta de celulose; na fração HDL não foi observada nenhuma alteração, mantendo-se igual em todos os tratamentos. A diferença na redução da concentração do colesterol plasmático entre a pectina e o psyllium pode ser devido a efeitos distintos destas fibras na absorção do colesterol (Turley et al., 1994), desintegração da micela (Furda \& Brine, 1990), ou na interferência da circulação entero-hepática dos ácidos biliares (Matheson \& Story, 1994). O colesterol total do figado foi reduzido em $30 \%$ e $36 \%$ para as dietas com pectina e psyllium quando comparadas ao controle (celulose).

No experimento de Moundras et al. (1997), que teve duração de vinte e um dias, o ganho de peso final dos animais não foi significativamente afetado pela adição de $0,3 \%$ de colesterol na dieta; no entanto, as dietas com 7,5\% de goma guar com ou sem colesterol proporcionaram ligeira redução do ganho de peso quando comparadas à dietacontrole (hipercolesterolêmica). O colesterol sangǘneo foi reduzido em $43 \%$ e $32 \%$, respectivamente para as dietas com $7,5 \%$ de goma guar sem colesterol e com colesterol em relação à dieta-controle. $O$ colesterol do figado foi reduzido em $82 \%$ e $72 \%$ para as dietas com goma guar sem e com colesterol quando comparada ao controle. 
No estudo de Gorinstein et al. (1998), o caqui apresentou o teor de fibra solúvel e insolúvel na matéria seca de $1,75 \%$ e $1,70 \%$ e duração de vinte e oito dias. A adição do caqui ou do colesterol nas dietas não afetaram a ingestão alimentar e o ganho de peso dos animais. Após o final do experimento, a concentração do colesterol total e do LDL colesterol sangüíneo em ambos os grupos alimentados com $1 \%$ de colesterol e $7 \%$ de caqui $+1 \%$ de colesterol foi maior do que nos grupos controle (sem fibra e sem colesterol) e com 7\% de caqui, e os animais que receberam a dieta com colesterol tiveram o colesterol total e o LDL - colesterol significativamente maior do que aqueles alimentados com caqui + colesterol. $O$ grupo alimentado com colesterol + caqui promoveu redução de $20 \%$ do colesterol total plasmático e de $31 \%$ do LDL - colesterol. A fração HDL - colesterol não foi alterada em nenhum grupo. A concentração do colesterol total do figado foi reduzida pelo grupo alimentado com colesterol + caqui em $34 \%$ quando comparado ao grupo que se alimentou com colesterol. Tais resultados foram atribuídos ao caqui pelo fato de este possuir altas concentrações de carotenóides, polifenóis (taninos), fibra solúvel e ácido ascórbico.

$\mathrm{Na}$ pesquisa de Verny et al. (2000), a dieta-controle $(0,2 \%$ de colesterol), $1 \%$ de goma guar e $1 \%$ de goma xantana, ambas acrescidas de $0,2 \%$ de colesterol, e duração de vinte e um dias, não proporcionaram diferença significativa no ganho de peso e no consumo alimentar dos animais. O colesterol total plasmático foi reduzido em $14 \%$ e $23 \%$ nas dietas com goma guar e goma xantana quando comparadas ao controle. $O$ colesterol do figado teve redução de $33 \%$ e $38 \%$ para as dietas acima citadas em relação ao controle; portanto, baixa concentração das gomas guar e xantana na dieta reduz o colesterol, devido ao fato de acelerar a excreção de esteróis e reduzir a absorção intestinal do colesterol. 


\section{MATERIAL E MÉTODOS}

\subsection{Caracterização da matéria-prima}

Para a realização deste estudo foi utilizado o resíduo do abacaxizeiro da cultivar Smooth Cayenne, proveniente do município de Guaraçai /S.P., sendo retirados do solo e imediatamente transportados para o Laboratório de Bromatologia e Nutrição Experimental do Departamento de Agroindústria, Alimentos e Nutrição da Escola Superior de Agricultura "Luiz de Queiroz" (ESALQ/USP). As plantas foram pesadas, fez-se a separação das folhas e caules, determinaram-se seus respectivos pesos, procedeu-se então ao fracionamento em picadora, e posterior secagem em estufa de circulação de ar forçada a $55^{\circ} \mathrm{C}$ até peso constante, moagem em moinho de facas e homogeneização. $\mathrm{O}$ material já seco e moído foi armazenado em sacos plásticos de polietileno para alimentos, e colocados em geladeira a $4^{\circ} \mathrm{C}$, para posterior utilização nas análises. Na realização do ensaio biológico foi utilizada como fonte de fibra solúvel padrão a pectina cítrica de alta metoxilação (HMP).

\subsection{Análises químicas do resíduo do abacaxizeiro}

Os teores de matéria seca, proteína bruta, extrato etéreo e cinza foram determinados de acordo com a metodologia recomendada pela AOAC (1975), ou seja:

- Para a obtenção da matéria seca, as amostras passaram por secagem em estufas a $105^{\circ} \mathrm{C}$, até peso constante (aproximadamente 14 horas), sendo a umidade obtida por diferença; 
- O teor de nitrogênio foi determinado pelo método de microkjeldahl, sendo o teor protéico obtido pela multiplicação do conteúdo de nitrogênio total pelo fator 6,25 ;

- A determinação de extrato etéreo foi realizada com o extrator de Soxhlet, utilizando como solvente o éter etílico;

- A cinza foi obtida calcinando-se as amostras em mufla à temperatura de $600^{\circ} \mathrm{C}$ por 4 horas;

- Os carboidratos digeríveis foram obtidos por diferença.

\subsection{Determinação de fibra solúvel e insolúvel}

Para a determinação do conteúdo de fibra foi empregado o método proposto por Asp et al. (1983), que emprega as enzimas $\alpha$ - amilase para promover a hidrólise do amido e pepsina, seguidas de pancreatina para a degradação da proteína

\subsection{Ensaio Biológico}

\subsubsection{Preparo das dietas utilizadas no ensaio biológico}

As dietas foram formuladas segundo o American Institute of Nutrition - 1993 (Reeves et al., 1993), com adição de banha de porco com $14 \%$ de colesterol, representando $7,5 \%$ do total da dieta, tendo, portanto, um total de $1,05 \mathrm{~g}$ de colesterol por $100 \mathrm{~g}$ de dieta (Paniangvait et al., 1995); estas foram consideradas hipercolesterolêmicas. Foi elaborada uma dieta sem adição de fibra, utilizada como controle.

A adição das fibras deu-se em detrimento do amido de milho, cuja fonte foi o produto comercial "Maizena". A caseína foi utilizada como fonte protéica. 
As dietas testadas foram:

- Dieta hipercolesterolêmica (controle);

- Dieta hipercolesterolêmica com $10 \%$ de resíduo do abacaxizeiro;

- Dieta hipercolesterolêmica com $15 \%$ de resíduo do abacaxizeiro;

- Dieta hipercolesterolêmica com $25 \%$ de resíduo do abacaxizeiro;

- Dieta hipercolesterolêmica com $10 \%$ de pectina;

- Dieta hipercolesterolêmica com 15\% de pectina;

- Dieta hipercolesterolêmica com $25 \%$ de pectina.

A Tabela 1 apresenta a composição das sete dietas avaliadas. Semanalmente foram elaborados $2 \mathrm{~kg}$ de cada dieta. Após o preparo, foram embalados em sacos plásticos, etiquetados e mantidos sob refrigeração a $4^{\circ} \mathrm{C}$.

TABELA 1. Composição das dietas experimentais: controle e suplementadas com o resíduo do abacaxizeiro e com a pectina $(\mathrm{g} / 100 \mathrm{~g})$.

\begin{tabular}{|c|c|c|c|c|c|c|c|}
\hline \multirow[t]{2}{*}{ Componentes } & \multicolumn{7}{|c|}{ Dietas } \\
\hline & Hiper* & $10 \%$ Res & $15 \%$ Res & $25 \%$ Res & 10\% Pec & $15 \%$ Pec & $25 \%$ Pec \\
\hline Caseína & 15,0 & 15,0 & 15,0 & 15,0 & 15,0 & 15,0 & 15,0 \\
\hline Banha de porco & 7,5 & 7,5 & 7,5 & 7,5 & 7,5 & 7,5 & 7,5 \\
\hline Mistura salina ${ }^{1}$ & 3,5 & 3,5 & 3,5 & 3,5 & 3,5 & 3,5 & 3,5 \\
\hline Mistura vitamínica ${ }^{1}$ & 1,0 & 1,0 & 1,0 & 1,0 & 1,0 & 1,0 & 1,0 \\
\hline Colina & 0,25 & 0,25 & 0,25 & 0,25 & 0,25 & 0,25 & 0,25 \\
\hline L-cistina & 0,3 & 0,3 & 0,3 & 0,3 & 0,3 & 0,3 & 0,3 \\
\hline Tertibutilhidroquinona & 0,0014 & 0,0014 & 0,0014 & 0,0014 & 0,0014 & 0,0014 & 0,0014 \\
\hline Sacarose & 10,0 & 10,0 & 10,0 & 10,0 & 10,0 & 10,0 & 10,0 \\
\hline Resíduo & 0 & 10 & 15 & 25 & 0 & 0 & 0 \\
\hline Pectina (HMP) & 0 & 0 & 0 & 0 & 10 & 15 & 25 \\
\hline Amido & 62,45 & 52,45 & 47,45 & 37,45 & 52,45 & 47,45 & 37,45 \\
\hline
\end{tabular}

*Dieta Controle

${ }^{1}$ Fonte: Reeves et al. (1993)

\subsubsection{Animais utilizados}

Utilizaram-se ratos machos (Rattus norvegicus var. albinos), da linhagem Wistar, obtidos de cruzamentos sucessivos do biotério do Departamento de Agroindústria, Alimentos e Nutrição da ESALQ/USP. No período pré-experimental, os animais, após 
serem desmamados, foram mantidos em gaiolas coletivas, à temperatura de $25^{\circ} \mathrm{C}$, com ciclo claro-escuro de 12 horas, e tiveram livre acesso à ração comercial Purina até atingir o peso de 150 a $175 \mathrm{~g}$. No início do período experimental, os animais com 12 semanas em média foram mantidos em gaiolas individuais, em ambiente com temperatura de $22^{\circ} \mathrm{C}$ a $23^{\circ} \mathrm{C}$. A iluminação ambiente foi controlada para 12 horas de luz e 12 horas de obscuridade.

Foram utilizados 132 animais, dos quais seis foram sacrificados no início do experimento, após jejum de 12 horas. $\mathrm{O}$ sangue desses animais foi coletado pela técnica de punção cardíaca, e os resultados das análises de colesterol total, HDL - colesterol e LDL - colesterol realizadas foram determinados inicialmente (T0).

Os demais animais foram divididos em 7 grupos, sendo que cada grupo foi utilizado para a avaliação das dietas elaboradas. Em cada grupo havia dezoito animais, sendo que seis ratos foram sacrificados aos 15 dias, outros seis, aos 30 dias, e os seis restantes, aos 45 dias de experimento.

Os animais receberam as dietas correspondentes a cada grupo e a água "ad libitum". Os pesos dos animais e a ingestão alimentar foram monitorados três vezes por semana, durante os 45 dias do experimento. No final de cada período, os animais foram sacrificados e submetidos a uma incisão das cavidades abdominal e torácica para a coleta de sangue por punção cardiaca. As amostras de sangue foram analisadas logo após a coleta.

As fezes dos animais foram coletadas e pesadas três vezes por semana, considerando-se os mesmos períodos, sendo acondicionadas em sacos plásticos individuais para cada rato e mantidas sob refrigeração. Após o período de coleta, as fezes foram limpas, pesadas e secas em estufa com circulação de ar forçada a $105^{\circ} \mathrm{C}$, durante 48 horas, e pesadas novamente para a determinação do peso úmido e seco. 


\subsubsection{Dosagem do colesterol sangüíneo total, HDL - colesterol e LDL - colesterol}

O conteúdo plásmatico de colesterol total e HDL - colesterol foi quantificado por teste enzimático colorimétrico, empregando-se o kit da indústria química clínica BioDiagnóstica Ltda (Colesterol BD 310-S). Os métodos utilizados para a determinação do Colesterol Total e HDL - colesterol seguem os procedimentos descritos por Allain et al., (1974) e o LDL, por diferença.

Segundo essa metodologia, o colesterol total foi determinado nas amostras de soro de acordo com as seguintes reações:

Ésteres de colesterol $\stackrel{\text { colesterol esterase }}{\longrightarrow}$ Colesterol + Ácidos Graxos

Colesterol $+\mathrm{O}_{2} \stackrel{\text { colesterol oxidase }}{\longrightarrow}$ Colest-4-en-3-ona $+\mathrm{H}_{2} \mathrm{O}_{2}$

$2 \mathrm{H}_{2} \mathrm{O}_{2}+4$-Aminoantipirina + fenol $\stackrel{\text { peroxidase }}{\longrightarrow}$ quinoneimina $+4 \mathrm{H}_{2} \mathrm{O}$

Estas reações resultam na formação de cor vermelha, cuja intensidade da cor é diretamente proporcional à concentração de colesterol na amostra. As leituras de absorbância foram feitas a $\lambda=500 \mathrm{~nm}$, utilizando-se espectrofotômetro BECKMAN DU 640.

A separação do HDL foi baseada na seletividade dos íons fosfotungstato e magnésio precipitando todas as lipoproteínas, à exceção da fração HDL. Após a centrifugação da amostra, o HDL-colesterol contido no sobrenadante foi determinado utilizando-se a metodologia para dosagem de colesterol total, descrita anteriormente.

\subsection{Colesterol total no figado}

No final de cada período, o figado dos animais foi retirado e então utilizado para a determinação do colesterol total no figado. 
O figado foi triturado, homogeneizado e pesado $0,5 \mathrm{~g}$; em seguida foi colocado em tubo de centrífuga, adicionando-se então $5 \mathrm{ml}$ de isopropanol, após o qual foi tampado e deixado por dois dias a $4^{\circ} \mathrm{C}$; em seguida a amostra foi centrifugada por 10 minutos a $1000 \mathrm{rpm}$, e a partir do sobrenadante (Haug \& Hostmark, 1987) foi feita a análise do colesterol total, seguindo a mesma metodologia já descrita para o colesterol total (item 3.4.3).

\subsubsection{Teor de lipídeos nas fezes}

As fezes secas foram moídas em moinho de facas e refrigeradas a $4^{\circ} \mathrm{C}$ para posterior análise de extrato etéreo. A determinação do teor de lipídeos foi realizada com o extrator de Soxhlet, utilizando como solvente o éter etílico, seguindo a metodologia descrita pela AOAC (1975).

\subsection{Análise estatística}

O delineamento experimental foi inteiramente casualizado com 7 tratamentos e 6 repetições (Gomes, 1982). Os tratamentos foram comparados através do teste $\mathrm{F}$ e, se significativo, foi realizado o teste de Tukey. Foi utilizado o programa SANEST. 


\section{RESULTADOS E DISCUSSÃO}

\subsection{Caracterização do resíduo do abacaxizeiro}

Foram utilizadas 80 plantas; o peso total do material foi de $256,14 \mathrm{~kg}$, sendo $172,20 \mathrm{~kg}$ de folhas e $34,28 \mathrm{~kg}$ dos caules. Foram descartados $30,98 \mathrm{~kg}$ e $18,67 \mathrm{~kg}$, respectivamente, de folhas e caules (Tabela 2).

TABELA 2. Porcentagem de folhas e caules do abacaxizeiro utilizados em relação ao total da planta.

\begin{tabular}{cc}
\hline \hline & $\%$ utilizadas em relação ao total da planta \\
\hline \hline Folhas & 67,3 \\
Caules & 13,4 \\
Descarte & 19,3 \\
\hline
\end{tabular}

\subsubsection{Composição química}

O teor de umidade encontrado na matéria "in natura" foi de $80,98 \%$.

Os resultados da composição centesimal do resíduo do abacaxizeiro encontramse na Tabela 3.

TABELA 3. Composição do resíduo do abacaxizeiro em matéria seca (g/100g).

\begin{tabular}{cc}
\hline Componentes* & Resíduo do abacaxizeiro \\
\hline Proteína & 2,61 \\
Cinza & 7,65 \\
Extrato etéreo & 6,76 \\
Fibra insolúvel & 42,05 \\
Fibra solúvel & 2,60 \\
Carboidratos disponíveis & 38,33 \\
\hline
\end{tabular}

*Médias de três repetições 


\subsection{Ensaio biológico}

\subsubsection{Consumo alimentar e ganho de peso}

Neste estudo, o consumo alimentar dos animais foi maior nas dietas acrescidas de resíduo do abacaxizeiro do que nas dietas de pectina, não havendo diferença significativa em relação à dieta hipercolesterolêmica nos diferentes níveis de concentração e duração do ensaio de 15 e 30 dias (Figura 1), diferindo dos estudos de Medellin et al. (1998), Alvarado et al. (1999) e Friedman et al. (2000), e concordando com os resultados de Rosa et al. (1998a; 1998b) e Shinnick et al. (1990). Para as dietas com pectina os resultados estão de acordo com os estudos de Arjmandi et al. (1992a; 1992b), e discordando dos resultados de Al-Othman et al. (1998) e Yamada et al. (1999), em que não houve redução significativa no consumo alimentar dos animais tratados com as dietas experimentais cuja fonte era de fibra solúvel.

Para as dietas com pectina, somente aos 45 dias de ensaio pôde-se observar que o aumento do nível de pectina da dieta reduz o consumo alimentar. Este comportamento pode ser atribuído ao caráter hidrofilico de certas fibras, como as pectinas e as gomas, que fazem com que a taxa de esvaziamento gástrico seja mais lenta, aumentando a saciedade, e consequentemente reduzindo a ingestão de alimentos (Fietz, 1998). 


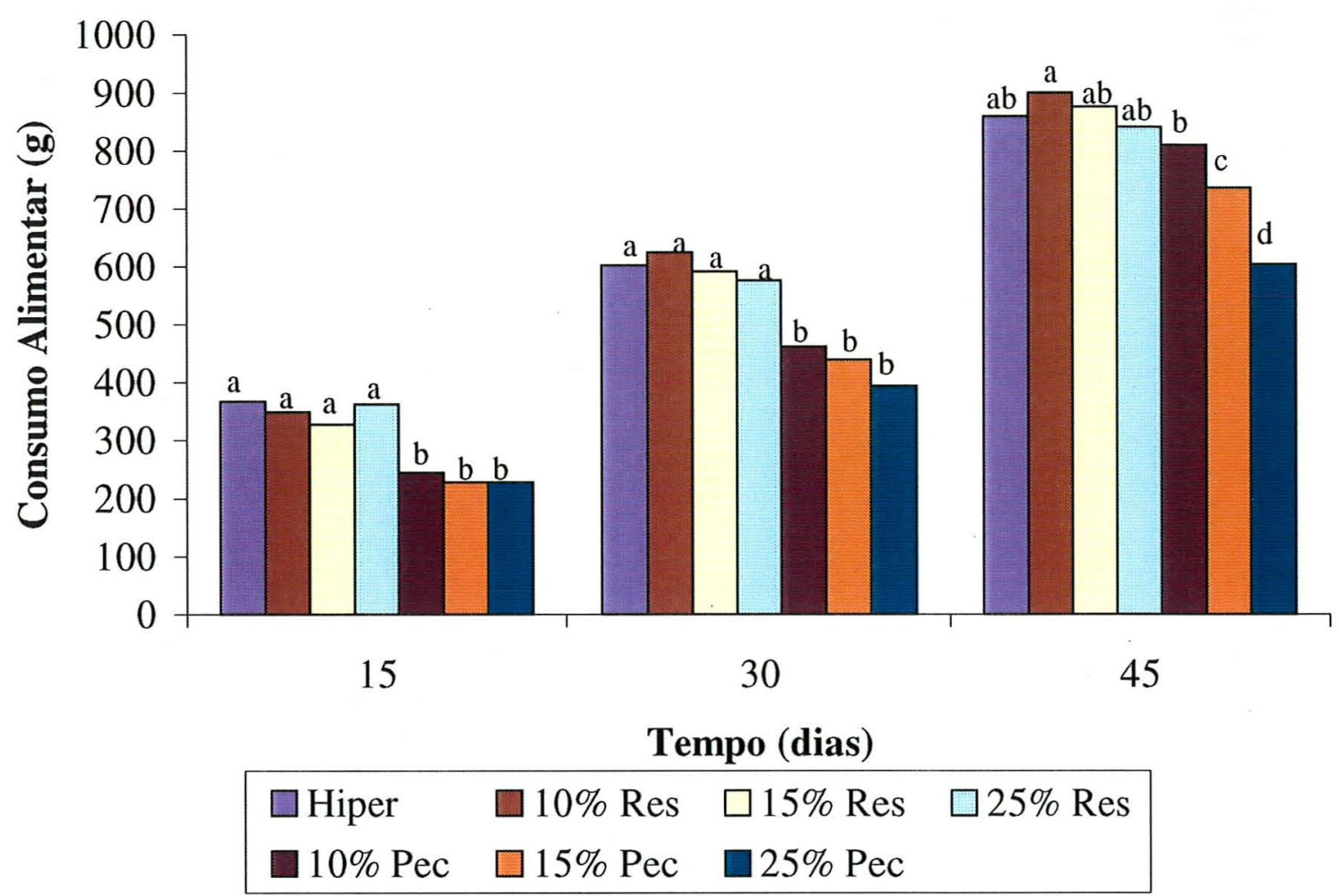

Figura 1 - Consumo alimentar das dietas experimentais nos períodos de ensaio de 15, 30 e 45 dias.

O presente trabalho promoveu redução no ganho de peso dos animais alimentados com as dietas acrescidas de pectina em relação à dieta hipercolesterolêmica, concordando com os trabalhos de Arjmandi et al. (1992a; 1992b), e discordando dos resultados apresentados por Al-Othman et al. (1998); Jimenez-Vergara et al. (1999) e Yamada et al. (1999), os quais não reduziram significativamente o ganho de peso dos animais.

Com o aumento nos níveis de pectina, observa-se uma redução acentuada no ganho de peso dos animais, principalmente aos 45 dias de ensaio, concordando com Fietz \& Salgado (1999), que constataram que os tratamentos com a adição de fibras dietéticas (pectina de alta e baixa metoxilação) proporcionaram menor ganho de peso do que a dieta-controle. O menor ganho de peso pode ser atribuído às concentrações elevadas de fibras dietéticas na alimentação, que proporcionam barreira física na absorção dos nutrientes, e aumentam a excreção fecal (Krothiewski,1984). Pode-se 
observar que a dieta hipercolesterolêmica foi o tratamento que proporcionou o maior ganho de peso nos animais (Figura 2). Vigne et al. (1987) também relataram que a média de ganho de peso final foi significativamente menor em animais alimentados com a pectina quando comparados àqueles alimentados com celulose.

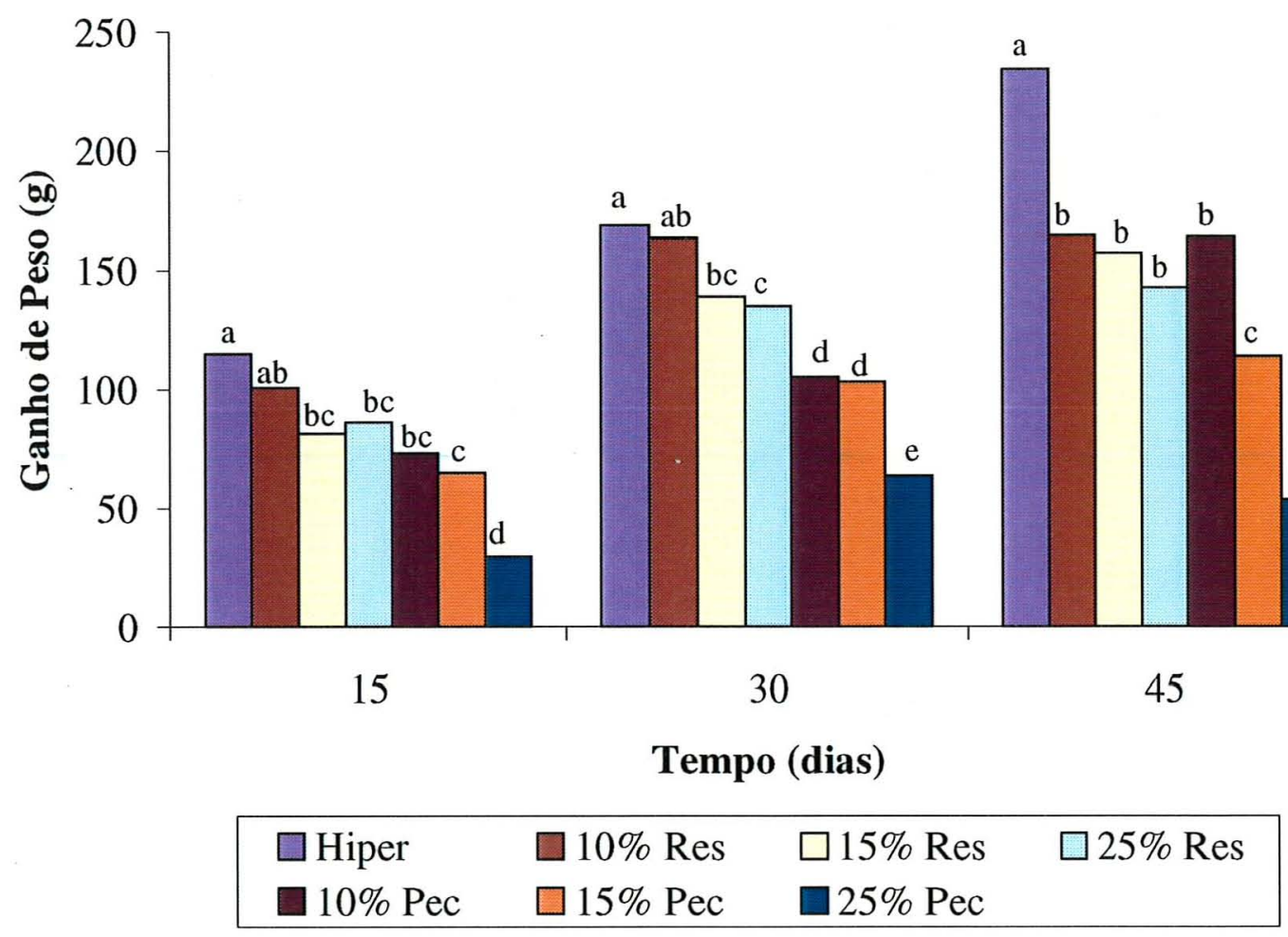

Figura 2 - Ganho de peso proporcionado pelas dietas experimentais nos períodos de ensaio de 15,30 e 45 dias.

Aos 15 dias de ensaio, as dietas acrescidas de resíduo do abacaxizeiro tiveram redução no ganho de peso, com exceção da dieta com $10 \%$ de resíduo, a qual não diferiu significativamente da dieta hipercolesterolêmica. As dietas com $15 \%$ e $25 \%$ de resíduo foram equivalentes a $10 \%$ e $15 \%$ de pectina. Aos 30 dias, as dietas de resíduo diferiram das dietas de pectina, sendo que a dieta com $10 \%$ de resíduo não diferiu da hipercolesterolêmica, como ocorreu no tempo 15, concordando com os estudos de Friedman et al. (2000) e Medellin et al. (1998), em que houve redução no ganho de peso dos animais, e discordando dos trabalhos de Alvarado et al. (1999); Rosa et al. (1998a; 
1998b) e Shinnick et al. (1990), que não obtiveram diferença no ganho de peso entre os grupos experimentais. Com 45 dias, o ganho de peso foi reduzido em todas as dietas do resíduo quando comparado à dieta hipercolesterolêmica, porém não diferindo da dieta com $10 \%$ de pectina, discordando do trabalho de Martín-Carrón et al. (2000), o qual não promoveu diferença significativa no ganho de peso dos animais alimentados com as dietas com os produtos de uva.

Os dados originais das figuras 1 e 2 são mostrados no Anexo.

\subsubsection{Colesterol total}

Os animais no tempo 0 apresentaram o colesterol total de $52,52 \mathrm{mg} / \mathrm{dl}$.

A Tabela 4 apresenta o efeito dos tratamentos nos níveis séricos do colesterol total, aos 15,30 e 45 dias de experimento.

Tabela 4. Concentração plasmática do colesterol total aos 15, 30 e 45 dias de duração do experimento com as dietas experimentais.

\begin{tabular}{|c|c|c|c|}
\hline \multicolumn{4}{|c|}{ Colesterol Total (mg/dl) } \\
\hline Dietas & 15 dias & 30 dias & 45 dias \\
\hline Hiper ${ }^{1}$ & $302,33^{2} \pm 43,6^{\mathrm{a3}}$ & $259,76 \pm 50,8^{a}$ & $320,06 \pm 30,3^{2}$ \\
\hline $10 \%$ Res & $249,09 \pm 5,3^{\mathrm{c}}$ & $227,69 \pm 23,5^{b}$ & $234,50 \pm 3,8^{b}$ \\
\hline $15 \% \operatorname{Res}$ & $268,15 \pm 3,0^{\mathrm{bc}}$ & $246,93 \pm 1,5^{\mathrm{ab}}$ & $244,41 \pm 2,3^{\mathrm{b}}$ \\
\hline $25 \%$ Res & $277,44 \pm 1,7^{\mathrm{ab}}$ & $254,06 \pm 2,1^{\mathrm{a}}$ & $251,41 \pm 5,0^{\mathrm{b}}$ \\
\hline $10 \%$ Pec & $185,73 \pm 1,2^{\mathrm{d}}$ & $180,26 \pm 2,3^{\mathrm{c}}$ & $164,01 \pm 2,2^{\mathrm{c}}$ \\
\hline $15 \%$ Pec & $181,25 \pm 3,8^{d}$ & $171,45 \pm 2,0^{\mathrm{c}}$ & $150,90 \pm 2,1^{\mathrm{c}}$ \\
\hline $25 \%$ Pec & $146,26 \pm 3,3^{\mathrm{e}}$ & $138,94 \pm 1,6^{d}$ & $138,97 \pm 1,0^{\mathrm{c}}$ \\
\hline
\end{tabular}

1 Sem adição de fibra;

2 Média \pm desvio-padrão de seis animais por tratamento;

3 Médias com letra (s) diferente (s) na vertical diferem significativamente em nível de $(p \leq 0,05)$.

Considerando-se o período do ensaio de 15 dias, o melhor resultado obtido na redução do colesterol total plasmático dos animais foi fornecido pela dieta de $25 \%$ de 
pectina, que proporcionou redução de $51,62 \%$ em relação à dieta hipercolesterolêmica. A dieta acrescida com $25 \%$ de resíduo não forneceu redução significativa. A dieta com $10 \%$ de resíduo obteve uma redução de $17,61 \%$ em relação à dieta-controle, não apresentando diferença significativa em relação à dieta com $15 \%$ de resíduo. Estes resultados discordam do estudo de Alvarado et al. (1999), que não promoveu redução significativa do colesterol total em relação à dieta-controle, e concordam com os trabalhos de Friedman et al. (2000) e Shinnick el al. (1990), os quais promoveram redução no colesterol total sangüineo.

No ensaio com os animais no período de 30 dias, observa-se redução significativa nos níveis plasmáticos do colesterol total. $\mathrm{O}$ melhor resultado obtido foi o da dieta com $25 \%$ de pectina, que promoveu uma redução de $46,51 \%$ do colesterol total em comparação ao controle. Entre os tratamentos com 10\% e 15\% de pectina não houve diferença significativa, mostrando que todos reduziram o colesterol total, concordando com os estudos de Al-Othman et al. (1998), Arjmandi et al. (1992a; 1992b), Anderson et al. (1994), Yamada et al. (1999) e Jimenez-Vergara et al. (1999), os quais concordam em que a pectina reduz os níveis séricos do colesterol total nos animais. Entre os tratamentos acrescidos com o resíduo do abacaxizeiro, a dieta com $10 \%$ de resíduo promoveu uma redução de $12,34 \%$ em relação à dieta hipercolesterolêmica; já as demais não apresentaram diferença significativa em relação à hipercolesterolêmica, discordando do estudo de Medellin et al. (1998), em que os teores do colesterol total não proporcionaram diferença significativa entre os tratamentos, e concordando com os trabalhos de Rosa et al. (1998a; 1998b) e Pérez-Olleros et al. (1999), os quais possuem dietas com fibras mistas e apresentaram redução no nível do colesterol total sangüíneo.

Aos 45 dias, pôde-se observar que a concentração plasmática do colesterol total foi reduzida em todos os tratamentos. A maior redução no colesterol total dos animais foi observada nas dietas com pectina, sendo que as dietas com o resíduo também proporcionaram a diminuição do colesterol, porém em menor intensidade que a da pectina, concordando com os trabalhos de Carter et al. (1998) e Vuorinen - Markkola et al. (1992), que demonstrou que a pectina e a goma guar são efetivas na redução do 
colesterol total em ratos e com o estudo de Martín-Carrón et al. (2000), em que dietas contendo fibras mistas reduziram os níveis do colesterol total.

Provavelmente a pectina é a fibra mais estudada na categoria das solúveis em água. Moundras et al. (1994) citam vários autores (Fernandez ${ }^{8}$ et al.,1992; Kay \& Truswell $^{9}, 1977$; Reddy $^{10}$ et al., 1980), que afirmam que a pectina serve de substrato para as bactérias e é fermentada no cólon do intestino grosso. Os produtos desta fermentação incluem hidrogênio, dióxido de carbono, metano, água e ácidos graxos de cadeia curta, como acetato, propionato e butirato. Esses ácidos graxos são quase totalmente absorvidos e podem interferir no metabolismo dos lipídeos e/ou alterar a absorção do colesterol e de ácidos biliares, possuindo, assim, efeito hipocolesterolêmico.

$\mathrm{Na}$ Figura 3, pode-se observar que a dieta hipercolesterolêmica possui a tendência de aumentar os níveis de colesterol total. Porém, com o incremento nas concentrações do resíduo e da pectina, os níveis do colesterol tenderam a se reduzir. A dieta com $25 \%$ de pectina promoveu o melhor controle do nível do colesterol total em todos os períodos. A pectina se constitui unicamente de fibra solúvel, já o resíduo possui $2,60 \%$ de fibra solúvel, e portanto promoveu uma menor redução. Estes resultados se mostram bons no controle do colesterol total, reduzindo-se assim o risco de enfermidades cardíacas.

\footnotetext{
${ }^{8}$ FERNANDEZ, M. L. et al. Prickly pear (Opuntia sp.) pectin revers low density lipoprotein receptor suppression induced by a hypercholesterolemic diet in guinea pigs. J. Nutr. 122: 2330-2340, 1992. ${ }^{9}$ KAY, R. M. \& TRUSWELL, A. S. Effect of citrus pectin on blood lipids and fecal steroid excretion in man. Am. J. Clin. Nutr. 30: 171-175,1977.

${ }^{10}$ REDDY, B. S. et al. Effect of dietary wheat bran, alfafa, pectin and carrageenan on plasma cholesterol and fecal bile acid and neutral sterol excretion in rats. J. Nutr. 110: 1247-1254, 1980.
} 


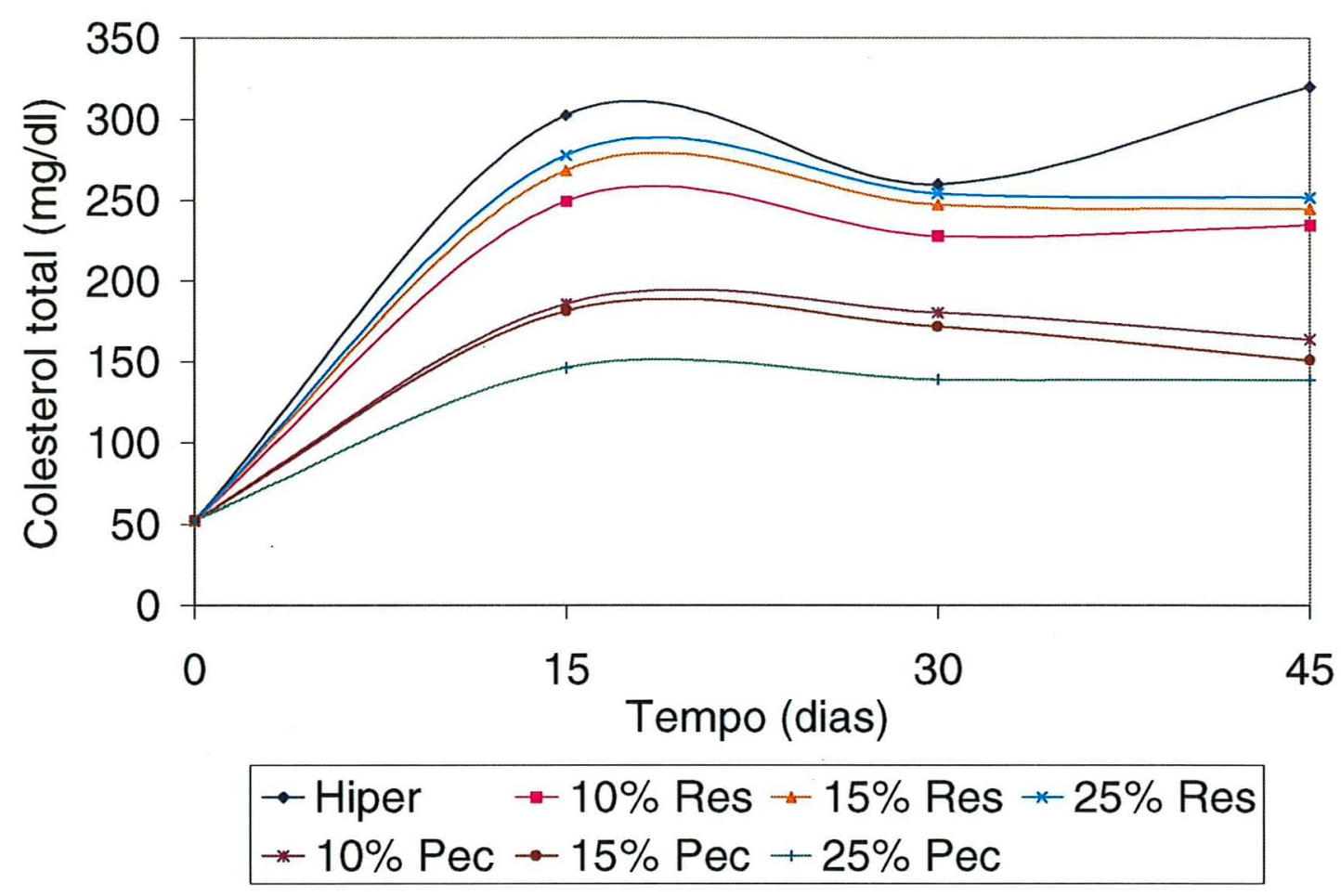

Figura 3. Concentração plasmática de colesterol total aos $0,15,30$ e 45 dias dos animais alimentados com as dietas experimentais.

Trabalhos com ratos demonstraram que fibras como psyllium, gomas e pectina são ricas em fibras solúveis, e promovem redução significativa nas concentrações do colesterol sangüíneo e do fígado (Jennings et al., 1988; Shinnick et al., 1990). Fibras mistas contendo ambas as frações solúveis e insolúveis (como a soja e o farelo de aveia) possuem efeito intermediário, enquanto as fibras que predominam a fração insolúvel da fibra (como o farelo de milho e o farelo de trigo) possuem um pequeno efeito no nível do colesterol plasmático e do fígado. Os resultados obtidos pelo resíduo do abacaxizeiro concordam com os autores acima, devido ao fato de este resíduo conter fibra mistas.

Em estudo realizado por Fietz (1998), praticamente todos os tratamentos produziram efeito no nível do colesterol. O melhor efeito foi observado nos níveis de $10 \%$ e $15 \%$ de pectina de alta metoxilação para os tempos de 15 e 30 dias, concordando com os resultados do presente trabalho, com os mesmos teores de pectina. Aos 45 dias 
houve redução nos níveis do colesterol, de acordo com o aumento da concentração da pectina de $5 \%, 10 \%$ e $15 \%$, discordando dos resultados deste trabalho, em que não houve diferença na redução do colesterol total com o aumento da concentração da pectina. Aos 15 e 30 dias, os tratamentos com 10\% e 15\% de celulose proporcionaram leve redução no nível do colesterol, e a dieta com $5 \%$ não apresentou diferença significativa em relação ao controle, resultados estes próximos aos obtidos por este trabalho das dietas com $10 \%$ e $15 \%$ do resíduo do abacaxizeiro aos 15 dias e $10 \%$ do resíduo do abacaxizeiro aos 30 dias de ensaio, os quais promoveram uma redução do colesterol. Os resultados estão de acordo com Jackson et al. (1994), que consideram que as fibras solúveis possuem efeito mais significativo do que as insolúveis em água no controle das hiperlipidemias.

\subsubsection{HDL - colesterol}

A concentração de colesterol total é importante, porém as quantidades de HDL colesterol e LDL - colesterol devem ser consideradas, já que o HDL é transportador do colesterol, devendo ser elevado, e o LDL é o que se acumula na parede das artérias, devendo estar presente em menor quantidade na corrente sangüínea (Jenkins et al., 1998).

No tempo 0 os animais apresentaram um nivel de HDL - colesterol de $33,91 \mathrm{mg} / \mathrm{dl}$.

A Tabela 5 apresenta o efeito das dietas experimentais no nível sérico do HDL colesterol aos 15,30 e 45 dias. 
Tabela 5. Concentração plasmática do HDL - colesterol aos 15, 30 e 45 dias de duração do experimento com as dietas experimentais.

\begin{tabular}{cccc}
\hline \hline & \multicolumn{3}{c}{ HDL - colesterol (mg/dl) } \\
\cline { 2 - 4 } Dietas & $\mathbf{1 5}$ dias & 30 dias & 45 dias \\
\hline \hline Hiper & $32,26^{2} \pm 7,2^{\mathrm{d} 3}$ & $25,91 \pm 2,5^{\mathrm{e}}$ & $26,17 \pm 6,7^{\mathrm{cd}}$ \\
$\mathbf{1 0 \%}$ Res & $97,60 \pm 1,5^{\mathrm{b}}$ & $31,73 \pm 1,5^{\mathrm{d}}$ & $17,25 \pm 1,5^{\mathrm{e}}$ \\
$\mathbf{1 5 \%}$ Res & $100,29 \pm 2,2^{\mathrm{ab}}$ & $38,42 \pm 1,7^{\mathrm{c}}$ & $23,99 \pm 1,2^{\mathrm{d}}$ \\
$\mathbf{2 5 \%}$ Res & $103,17 \pm 1,5^{\mathrm{a}}$ & $44,77 \pm 1,7^{\mathrm{b}}$ & $29,24 \pm 1,6^{\mathrm{c}}$ \\
$\mathbf{1 0 \%}$ Pec & $53,36 \pm 1,2^{\mathrm{c}}$ & $53,20 \pm 0,9^{\mathrm{a}}$ & $40,26 \pm 1,9^{\mathrm{a}}$ \\
$\mathbf{1 5 \%}$ Pec & $49,92 \pm 0,7^{\mathrm{c}}$ & $42,59 \pm 1,1^{\mathrm{bc}}$ & $37,19 \pm 0,8^{\mathrm{ab}}$ \\
$\mathbf{2 5 \% ~ P e c}$ & $27,28 \pm 4,3^{\mathrm{e}}$ & $21,69 \pm 2,7^{\mathrm{e}}$ & $33,74 \pm 1,5^{\mathrm{b}}$ \\
\hline \hline
\end{tabular}

1 Sem adição de fibra;

2 Média \pm desvio-padrão de seis animais por tratamento;

3 Médias com letra (s) diferente (s) na vertical diferem significativamente em nível de $(p \leq 0,05)$.

Aos 15 dias de experimento, a concentração plasmática do HDL - colesterol foi aumentada em quase todas as dietas, com exceção da dieta com $25 \%$ de pectina, que proporcionou redução no nível do HDL quando comparada à dieta hipercolesterolêmica. Os melhores resultados observados foram os das dietas com $25 \%$ e $15 \%$ de resíduo, que proporcionaram aumento no nível do HDL - colesterol de $219,80 \%$ e $210,88 \%$, respectivamente, em relação à dieta-controle, sendo que estas não apresentaram diferença significativa entre si, não concordando com o estudo de Alvarado et al. (1999), que não proporcionou aumento significativo do $\mathrm{HDL}$ em relação à dieta-controle. As dietas com $10 \%$ e $15 \%$ de pectina apresentaram valores inferiores no nivel do HDL colesterol, quando comparadas às dietas com o resíduo.

A fração HDL - colesterol foi aumentada em quase todos os tratamentos com duração de 30 dias, com exceção da dieta com $25 \%$ de pectina, que apresentou o nível do HDL - colesterol igual ao da dieta hipercolesterolêmica. $\mathrm{O}$ melhor resultado observado foi o da dieta com $10 \%$ de pectina, que promoveu aumento da fração HDL - 
colesterol de 105,33\% em relação à dieta-controle. As demais dietas também proporcionaram aumento do HDL - colesterol, só que em menor intensidade que a de $10 \%$ de pectina. Estes resultados concordam com os de Al-Othman et al. (1998), o qual verificou que a dieta de 7,5\% goma arábica proporcionou aumento do $\mathrm{HDL}$ - colesterol quando comparada à dieta de celulose, discordando do estudo de Jimenez-Vergara et al. (1999), em que o nível do HDL- colesterol foi mantido igual ao da dieta-controle. Os resultados do resíduo não estão de acordo com Medellín et al. (1998), Friedman et al. (2000) e Rosa et al. (1998a), que não observaram aumento significativo do HDL colesterol entre os tratamentos.

No ensaio com 45 dias, a concentração plasmática da fração HDL - colesterol foi aumentada somente nas dietas acrescidas de pectina. Os melhores resultados foram os das dietas com $10 \%$ e $15 \%$ de pectina, que promoveram aumento na concentração plasmática de $53,84 \%$ e $42,11 \%$ em comparação à dieta-controle. O HDL - colesterol não foi alterado quando comparadas a dieta hipercolesterolêmica com as dietas acrescidas do resíduo, com exceção da dieta com 10\% de resíduo, que proporcionou uma redução da fração HDL - colesterol em relação à dieta-controle, discordando do trabalho de Martín-Carrón et al. (2000), em que o HDL - colesterol foi aumentado com 10\% de produtos de uva.

Segundo Fietz (1998), aos 30 dias de ensaio, os níveis de HDL praticamente não se modificaram com o aumento das concentrações da pectina de alta metoxilação (HMP) e baixa metoxilação (LMP). As dietas-controle e com 5\% de HMP não diferiram estatisticamente, enquanto as demais produziram um aumento significativo dos níveis séricos. Aos 45 dias, as dietas com 10\% e 15\% de HMP produziram aumento significativo da fração $\mathrm{HDL}$ em relação ao controle, concordando com os valores encontrados neste estudo. 


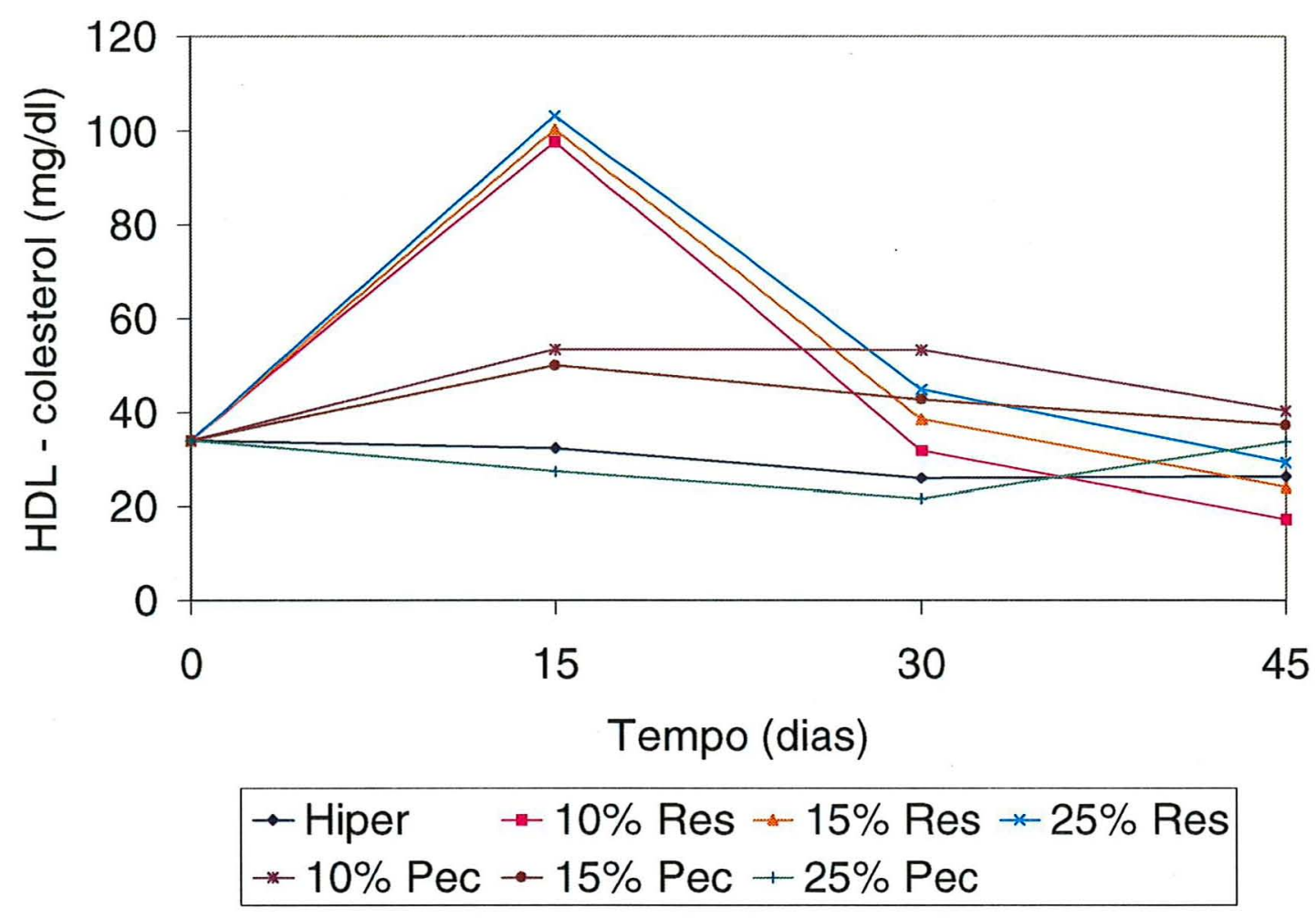

Figura 4. Concentração plasmática do HDL - colesterol aos 0, 15, 30 e 45 dias dos animais alimentados com as dietas experimentais.

Até aos 30 dias de ensaio, praticamente todas as dietas aumentaram os níveis séricos da fração HDL - colesterol (Figura 4), com exceção da dieta com $25 \%$ de pectina, que promoveu redução. No período de 30 a 45 dias as dietas adicionadas com a pectina proporcionaram tendência de aumento do HDL, sendo que as dietas com o resíduo promoveram o inverso. Estes resultados estão de acordo com Fietz (1998) e Dreher (1987), em que a ingestão de pectina pode aumentar os níveis plasmáticos da fração HDL - colesterol quando a dieta for hiperlipidêmica, e discordando dos resultados obtidos por Carter et al. (1998), em que o HDL dos ratos alimentados com dietas com $0 \%$ de fibra, $5 \%$ de celulose, 5 ou $10 \%$ de lignina foi significativamente maior do que aqueles que consumiram as dietas com $5 \%$ e $10 \%$ de pectina, ou $5 \%$ e $10 \%$ de goma guar-- O HDL dos ratos que consumiram a dieta de $10 \%$ de celulose foi significativamente maior do que dos da dieta com 10\% de goma guar, concordando com 
os resultados do resíduo aos 15 dias, em que as fibras insolúveis foram mais efetivas no aumento do HDL - colesterol do que as solúveis.

\subsubsection{LDL - colesterol}

Os animais no tempo 0 apresentaram um nível de LDL - colesterol de $18,67 \mathrm{mg} / \mathrm{dl}$.

Na Tabela 6 pode-se observar o efeito das dietas experimentais no nível sérico do LDL - colesterol aos 15, 30 e 45 dias de experimento.

Tabela 6. Concentração plasmática do LDL - colesterol aos 15, 30 e 45 dias de duração do experimento com as dietas experimentais.

\begin{tabular}{cccc}
\hline & \multicolumn{3}{c}{ LDL - colesterol (mg/dl) } \\
\cline { 2 - 4 } Dietas & $\mathbf{1 5}$ dias & $\mathbf{3 0}$ dias & $\mathbf{4 5}$ dias \\
\hline \hline Hiper $^{\mathbf{l}}$ & $270,05^{2} \pm 39,1^{\mathrm{a} 3}$ & $233,85 \pm 48,5^{\mathrm{a}}$ & $293,88 \pm 28,5^{\mathrm{a}}$ \\
$\mathbf{1 0 \%}$ Res & $151,49 \pm 5,5^{\mathrm{bc}}$ & $195,96 \pm 24,0^{\mathrm{b}}$ & $216,05 \pm 4,1^{\mathrm{b}}$ \\
$\mathbf{1 5 \%}$ Res & $167,86 \pm 3,5^{\mathrm{b}}$ & $208,50 \pm 1,8^{\mathrm{b}}$ & $220,42 \pm 1,7^{\mathrm{b}}$ \\
$\mathbf{2 5} \%$ Res & $174,27 \pm 1,0^{\mathrm{b}}$ & $209,28 \pm 3,2^{\mathrm{b}}$ & $222,16 \pm 6,4^{\mathrm{b}}$ \\
$\mathbf{1 0} \%$ Pec & $132,37 \pm 1,6^{\mathrm{cd}}$ & $127,06 \pm 2,8^{\mathrm{c}}$ & $123,75 \pm 2,7^{\mathrm{c}}$ \\
$\mathbf{1 5 \%}$ Pec & $131,33 \pm 4,1^{\text {cd }}$ & $128,85 \pm 2,4^{\mathrm{c}}$ & $113,71 \pm 2,1^{\mathrm{c}}$ \\
$\mathbf{2 5 \%}$ Pec & $118,98 \pm 6,2^{\mathrm{d}}$ & $117,25 \pm 2,4^{\mathrm{c}}$ & $105,23 \pm 2,2^{\mathrm{c}}$ \\
\hline \hline
\end{tabular}

1 Sem adição de fibra;

2 Média \pm desvio-padrão de seis animais por tratamento;

3 Médias com letra (s) diferente (s) na vertical diferem significativamente em nível de $(p \leq 0,05)$.

Aos 15, 30 e 45 dias de experimento, o LDL - colesterol foi reduzido em todos os tratamentos em relação à dieta hipercolesterolêmica. Os melhores resultados observados na redução do LDL - colesterol foram os das dietas acrescidas com pectina, não havendo diferença significativa nos níveis de $10 \%, 15 \%$ e $25 \%$, concordando com o estudo de Jimenez-Vergara et al. (1999), em que o nível do LDL - colesterol foi 
reduzido quando os animais ingeriram dietas ricas em fibra solúvel. As dietas com o resíduo também proporcionaram uma diminuição do LDL - colesterol, porém em menor quantidade quando comparadas entre si, sendo que aos 15 dias a dieta de $10 \%$ de resíduo apresentou valor igual a de $10 \%$ e $15 \%$ de pectina. Os valores do resíduo concordam com Medellin et al. (1998), Friedman et al. (2000) e Martín-Carrón et al. (2000), em que fibras mistas reduzem o LDL - colesterol, e discordam do resultado de Alvarado et al. (1999) de que o RIT não reduziu o LDL em relação à dieta-controle.

Resultado semelhante foi encontrado por Fietz (1998), em que as concentrações plasmáticas da fração LDL - colesterol foram reduzidas em todos os tratamentos, menos no controle. Porém, as dietas com $10 \%$ e $15 \%$ de HMP foram as mais significativas aos 30 e 45 dias de ensaio, confirmando o presente estudo. Segundo Anderson et al. (1990a) e Carter et al. (1998), a redução dos níveis séricos da fração LDL - colesterol deve-se ao aumento da ingestão de fibras solúveis, que aumenta a fermentação e a produção de ácidos graxos voláteis, cujo mecanismo, indiretamente, reduz a síntese dessa fração. AlOthman et al. (1998) mostraram que a dieta com $7,5 \%$ de goma arábica não reduziu o LDL - colesterol quando comparada à dieta de celulose, discordando dos resultados do presente trabalho.

A Figura 5 mostra uma tendência de aumento da fração LDL - colesterol até aos 15 dias para a pectina, e até aos 45 dias para o resíduo. As dietas com pectina produziram maior redução nos níveis do LDL - colesterol; as dietas com o resíduo também proporcionaram redução, porém em menor intensidade, como ocorreu no colesterol total. Estes resultados estão de acordo com Thakur et al. (1997), em que a pectina pode reduzir os níveis séricos da fração LDL - colesterol. 


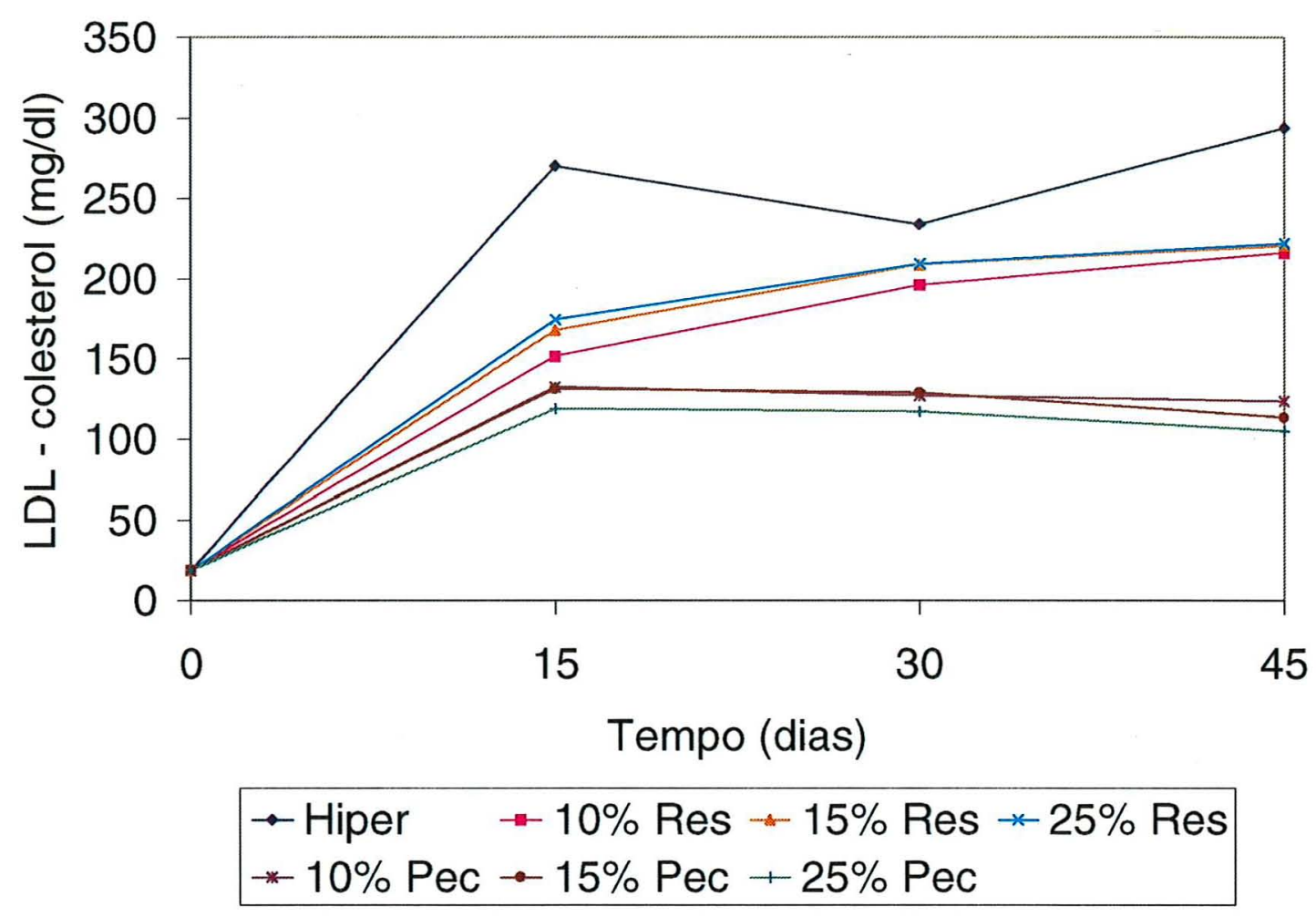

Figura 5. Concentração plasmática do LDL - colesterol aos 0, 15, 30 e 45 dias dos animais alimentados com as dietas experimentais.

As dietas com o resíduo proporcionaram reduções significativas nos níveis séricos do LDL - colesterol e do colesterol total. O controle das concentrações sangüíneas desses elementos é importante na prevenção de doenças coronárias. Portanto, conclui-se que o resíduo pode ser benéfico na prevenção de doenças coronarianas.

\subsubsection{Colesterol total do fígado}

A Tabela 7 apresenta o efeito dos tratamentos no nível do colesterol total hepático dos animais, aos 15, 30 e 45 dias de experimento. 
Tabela 7. Concentração do colesterol total no figado dos ratos aos 15, 30 e 45 dias de duração do experimento com as dietas experimentais.

\begin{tabular}{cccc}
\hline & \multicolumn{2}{c}{ Colesterol total no figado(mg/d) } & \\
\cline { 2 - 4 } Dietas & $\mathbf{1 5}$ dias & $\mathbf{3 0 ~ d i a s}$ & $\mathbf{4 5}$ dias \\
\hline \hline Hiper $^{\mathbf{1}}$ & $1,19^{2} \pm 0,1^{\mathrm{a3}}$ & $0,88 \pm 0,2^{\mathrm{a}}$ & $0,99 \pm 0,1^{\mathrm{a}}$ \\
$\mathbf{1 0 \%}$ Res & $0,72 \pm 0,1^{\mathrm{bc}}$ & $0,76 \pm 0,1^{\mathrm{ab}}$ & $0,67 \pm 0,1^{\mathrm{bc}}$ \\
$\mathbf{1 5 \%}$ Res & $0,68 \pm 0,1^{\mathrm{bc}}$ & $0,56 \pm 0,1^{\mathrm{bc}}$ & $0,64 \pm 0,1^{\mathrm{bc}}$ \\
$\mathbf{2 5 \%}$ Res & $0,85 \pm 0,2^{\mathrm{b}}$ & $0,76 \pm 0,2^{\mathrm{ab}}$ & $0,77 \pm 0,2^{\mathrm{abc}}$ \\
$\mathbf{1 0 \%}$ Pec & $0,59 \pm 0,1^{\mathrm{cd}}$ & $0,50 \pm 0,1^{\mathrm{c}}$ & $0,96 \pm 0,1^{\mathrm{a}}$ \\
$\mathbf{1 5 \%}$ Pec & $0,46 \pm 0,1^{\mathrm{d}}$ & $0,48 \pm 0,1^{\mathrm{c}}$ & $0,81 \pm 0,1^{\mathrm{ab}}$ \\
$\mathbf{2 5 \%}$ Pec & $0,62 \pm 0,2^{\text {cd }}$ & $0,68 \pm 0,1^{\mathrm{abc}}$ & $0,63 \pm 0,1^{\mathrm{bc}}$ \\
\hline \hline
\end{tabular}

1 Sem adição de fibra;

2 Média \pm desvio-padrão de seis animais por tratamento;

3 Médias com letra (s) diferente(s) na vertical diferem significativamente em nivel de $(p \leq 0,05)$.

Considerando-se o período do ensaio de 15 dias, observa-se que todas as dietas reduziram o colesterol total do figado. Os melhores resultados obtidos na redução do colesterol do figado foram fornecidos pelas dietas com $10 \%, 15 \%$ e $25 \%$ de pectina, as quais proporcionaram redução de $50,42 \%, 61,34 \%$ e $47,89 \%$ em relação à dieta hipercolesterolêmica, sendo que não apresentaram diferença significativa entre si. As dietas acrescidas de $10 \%, 15 \%$ e $25 \%$ de resíduo reduziram os níveis do colesterol total do figado em $39,49 \%, 42,85 \%$ e $28,57 \%$ em relação ao controle, não apresentando diferença entre si, concordando com o trabalho de Shinnick et al. (1990), que promoveu redução do colesterol do figado para as dietas com fibras mistas. As dietas de $10 \% \mathrm{e}$ $15 \%$ de resíduo não diferiram das dietas com $10 \%$ e $25 \%$ de pectina.

No ensaio com os animais no periodo de 30 dias, observa-se que as dietas com $10 \%$ e $25 \%$ de resíduo e a dieta com $25 \%$ de pectina mantiveram os níveis do colesterol total do figado iguais ao da dieta-controle, como pode ser observado na Tabela 7. A melhor redução do colesterol do figado foi fornecida pela dieta com $15 \%$ de pectina, a qual promoveu diminuição de $45,45 \%$ em relação à dieta hipercolesterolêmica. As dietas 
com $10 \%$ de pectina e $15 \%$ de resíduo também reduziram esse nível, e não diferiram da dieta com 15\% de pectina, concordando com os trabalhos de Arjmandi et al. (1992a; 1992b), Anderson et al. (1994), Moundras et al. (1997), Gorinstein et al. (1998), Jimenez-Vergara et al. (1999) e Verny et al. (2000), os quais obtiveram resultados em que o colesterol total do figado dos animais foi reduzido e concordam em que as fibras solúveis reduzem o colesterol, devido ao fato de acelerar a excreção de esteróis e reduzir a absorção intestinal do colesterol.

Aos 45 dias, pôde-se observar que o colesterol total do figado foi reduzido pelas dietas com $10 \%$ e $15 \%$ de resíduo e $25 \%$ de pectina, sendo que estas não diferiram estatisticamente entre si, e proporcionaram redução de $32,32 \%, 35,35 \%$ e $36,36 \%$, respectivamente, em relação à dieta hipercolesterolêmica. No entanto, as dietas com $25 \%$ de resíduo e $10 \%$ e $15 \%$ de pectina mantiveram o nível do colesterol total do figado igual ao da dieta controle.

Este estudo confirma estudos prévios em ratos que demonstraram que fibras solúveis promovem redução significativa nas concentrações do colesterol sanguiíneo e do figado; fibras mistas possuem efeito intermediário, enquanto fibras insolúveis possuem um pequeno efeito no nível do colesterol plasmático e do figado (Jennings et al., 1988; Shinnick et al., 1990).

\subsubsection{Teor de lipídeos nas fezes dos animais}

Na Tabela 8 pode-se observar o efeito das dietas experimentais na excreção fecal de lipídeos dos animais. 
Tabela 8. Teor de lipídeos das fezes dos animais, na matéria seca.

\begin{tabular}{cc}
\hline & Lipídeos nas fezes(\% M. S.) \\
\cline { 2 - 2 } Dietas & $7,94^{2} \pm 1,0^{\mathrm{b3}}$ \\
\hline \hline Hiper $\mathbf{1}^{\mathrm{b}}$ & $5,97 \pm 0,5^{\mathrm{bc}}$ \\
$\mathbf{1 0 \% \text { Res }}$ & $5,12 \pm 0,7^{\mathrm{c}}$ \\
$\mathbf{1 5 \% \text { Res }}$ & $5,02 \pm 0,2^{\mathrm{c}}$ \\
$\mathbf{2 5 \% \text { Res }}$ & $7,88 \pm 0,7^{\mathrm{b}}$ \\
$\mathbf{1 0 \% \text { Pec }}$ & $13,87 \pm 1,5^{\mathrm{a}}$ \\
$\mathbf{2 5 \% \text { Pec }}$ & $13,89 \pm 2,0^{\mathrm{a}}$ \\
\hline \hline
\end{tabular}

1 Sem adição de fibra;

2 Média \pm desvio-padrão de seis animais por tratamento;

3 Médias com letra (s) diferente (s) na vertical diferem significativamente em nível de $(p \leq 0,05)$.

No experimento, pode-se observar que as dietas com $15 \%$ e $25 \%$ de pectina promoveram aumento de $74,68 \%$ e $74,93 \%$ da excreção de lipídeos na fezes em relação à dieta hipercolesterolêmica. As dietas com $10 \%$ de pectina e $10 \%$ de resíduo mantiveram a excreção fecal de lipídeos igual ao da dieta-controle e as dietas com $15 \%$ e $25 \%$ de resíduo proporcionaram excreção de lipídeos menor que a da dieta-controle. Estes resultados discordam dos estudos de Pérez-Olleros et al. (1999) e Martín- Carrón et al. (2000), os quais testaram dietas com fibras mistas e observaram aumento na excreção fecal de lipídeos pelos animais. Rosa et al. (1998a) encontraram resultados semelhantes à dieta com $10 \%$ de resíduo, o qual não apresentou diferença significativa na excreção fecal de lipídeos entre as dietas experimentais e a controle. Porém, discorda dos valores encontrados para $15 \%$ e $25 \%$ de resíduo. 


\section{CONCLUSÕES}

A análise e interpretação dos resultados obtidos no estudo permitiram concluir que:

- A partir dos resultados obtidos com ratos, pode-se sugerir que o resíduo do abacaxizeiro tem potencial para ser utilizado como fonte de fibra. As melhores concentrações foram com $10 \%$ e $15 \%$ de resíduo na dieta;

- O consumo alimentar foi aumentado com o decorrer do tempo, sendo que as dietas do resíduo proporcionaram maior ingestão alimentar quando comparadas às dietas de pectina;

- A dieta hipercolesterolêmica e a dieta com $10 \%$ de resíduo foram as que tiveram o maior ganho de peso nos tempos 15 e 30 dias; aos 45 dias, somente a dietacontrole. $\mathrm{O}$ resíduo promoveu um ganho de peso intermediário, e a pectina, $\mathrm{O}$ menor ganho de peso;

- Os tratamentos com a pectina foram mais efetivos na redução do colesterol total. A dieta com $25 \%$ de pectina apresentou maior capacidade de reduzir os níveis séricos do colesterol total aos 15 e 30 dias de ensaio, não havendo diferença entre as dietas de pectina aos 45 dias;

- Aos 15 dias, as dietas com $10 \%$ e $15 \%$ de resíduo proporcionaram redução no nível do colesterol total. A dieta com $10 \%$ de resíduo foi a única que reduziu o colesterol aos 30 dias. Com 45 dias, todas as dietas promoveram redução; 
- A concentração plasmática do HDL - colesterol foi aumentada em quase todas as dietas, com exceção da dieta com $25 \%$ de pectina, que reduziu esse nível aos 15 , e aos 30 dias o manteve igual ao da dieta hipercolesterolêmica e das dietas com o resíduo do abacaxiziero aos 45 dias, existindo uma tendência de aumento do HDL - colesterol para as dietas com pectina, e de diminuição para as dietas com resíduo com o passar do tempo;

- Aos 15, 30 e 45 dias de ensaio o LDL - colesterol foi reduzido em todos os tratamentos. Os melhores resultados observados na redução do LDL foram os das dietas acrescidas de pectina. As dietas com o resíduo promoveram diminuição do LDL - colesterol, porém em menor intensidade do que a pectina, por ser uma fibra mista com frações solúveis e insolúveis;

- Considerando-se o período do ensaio de 15 dias, observa-se que todas as dietas reduziram o colesterol total do figado; no entanto, as dietas com pectina foram mais efetivas na redução do que as dietas com o resíduo. No tempo de 30 dias, a melhor redução do colesterol do figado foi fornecida pelas dietas com $10 \%$ e $15 \%$ de pectina e $15 \%$ de resíduo em relação ao controle. Aos 45 dias, pode-se observar que o colesterol total do figado foi reduzido pelas dietas com $10 \%$ e $15 \%$ de resíduo e $25 \%$ de pectina. Portanto, há alteração do teor de colesterol no figado de acordo com o tempo de consumo da dieta;

- Pode-se observar que as dietas com $15 \%$ e $25 \%$ de pectina promoveram aumento da excreção de lipídeos nas fezes, e que as dietas com $10 \%$ de resíduo e $10 \%$ de pectina mantiveram a quantidade de lipídeos igual ao da dieta-controle, e as dietas com $15 \%$ e $25 \%$ de resíduo diminuíram essa quantidade. 


\section{ANEXO}

Nas Tabelas em anexo, estão sendo apresentados os dados originais das figuras 1 e 2 do consumo alimentar e ganho de peso dos animais alimentados com as dietas experimentais.

TABELA - Consumo alimentar dos animais tratados com as dietas experimentais no período de 15,30 e 45 dias.

\begin{tabular}{|c|c|c|c|}
\hline \multicolumn{4}{|c|}{ Consumo Alimentar (g) } \\
\hline Dietas & 15 dias & 30 dias & 45 dias \\
\hline Hiper $^{1}$ & $366,80^{2} \pm 10,9^{a 3}$ & $601,55 \pm 51,6^{a}$ & $858,76 \pm 50,3^{\mathrm{ab}}$ \\
\hline $10 \%$ Res & $348,56 \pm 17,0^{\mathrm{a}}$ & $623,25 \pm 19,7^{a}$ & $899,50 \pm 70,6^{a}$ \\
\hline $15 \%$ Res & $326,66 \pm 32,5^{a}$ & $590,50 \pm 35,8^{a}$ & $875,00 \pm 45,3^{\mathrm{ab}}$ \\
\hline $25 \% \operatorname{Res}$ & $362,16 \pm 24,0^{\mathrm{a}}$ & $575,16 \pm 64,5^{\mathrm{a}}$ & $840,91 \pm 63,9^{\mathrm{ab}}$ \\
\hline $10 \%$ Pec & $242,92 \pm 20,2^{b}$ & $460,91 \pm 39,6^{b}$ & $809,33 \pm 39,7^{b}$ \\
\hline 15\% Pec & $226,92 \pm 11,4^{b}$ & $439,00 \pm 32,6^{b}$ & $736,16 \pm 26,8^{\mathrm{c}}$ \\
\hline $25 \%$ Pec & $227,33 \pm 10,8^{b}$ & $392,00 \pm 28,8^{b}$ & $603,08 \pm 62,1^{d}$ \\
\hline
\end{tabular}

1 Sem adição de fibra;

2 Média \pm desvio-padrão de seis animais por tratamento;

3 Médias com letra (s) diferente (s) na vertical diferem significativamente em nível de $(p \leq 0,05)$.

TABELA - Ganho de Peso dos animais tratados com as dietas experimentais no período de 15,30 e 45 dias.

\begin{tabular}{cccc}
\hline & \multicolumn{3}{c}{ Ganho de Peso (g) } \\
\cline { 2 - 4 } Dietas & 15 dias & 30 dias & 45 dias \\
\hline \hline Hiper $^{\mathbf{1}}$ & $114,91^{\mathbf{2}} \pm 9,7^{\mathrm{a}}$ & $168,58 \pm 23,0^{\mathrm{a}}$ & $234.19 \pm 20,8^{\mathrm{a}}$ \\
$\mathbf{1 0 \%}$ Res & $100,78 \pm 5,9^{\mathrm{ab}}$ & $163,54 \pm 21,7^{\mathrm{ab}}$ & $164,45 \pm 16,5^{\mathrm{b}}$ \\
$\mathbf{1 5 \%}$ Res & $81,28 \pm 11,0^{\mathrm{bc}}$ & $138,88 \pm 31,6^{\mathrm{bc}}$ & $157,33 \pm 24,6^{\mathrm{b}}$ \\
$\mathbf{2 5 \%}$ Res & $86,15 \pm 7,2^{\mathrm{bc}}$ & $134,93 \pm 26,3^{\mathrm{c}}$ & $142,73 \pm 36,0^{\mathrm{b}}$ \\
$\mathbf{1 0 \%}$ Pec & $73,25 \pm 14,2^{\mathrm{bc}}$ & $105,16 \pm 13,3^{\mathrm{d}}$ & $164,01 \pm 21,3^{\mathrm{b}}$ \\
$\mathbf{1 5 \%}$ Pec & $65,00 \pm 5,3^{\mathrm{c}}$ & $103,16 \pm 18,0^{\mathrm{d}}$ & $113,78 \pm 16,3^{\mathrm{c}}$ \\
$\mathbf{2 5 \%}$ Pec & $29,50 \pm 8,6^{\mathrm{d}}$ & $63,75 \pm 17,0^{\mathrm{e}}$ & $53,58 \pm 25,6^{\mathrm{d}}$ \\
\hline \hline
\end{tabular}

1 Sem adição de fibra;

2 Média \pm desvio-padrão de seis animais por tratamento, (exceto para G.P. da dieta com $25 \%$ Pectina e período do ensaio de 45 dias com cinco repetições);

3 Médias com letra (s) diferente ( $s$ ) na vertical diferem significativamente em nível de $(p \leq 0,05)$. 


\section{REFERÊNCIAS BIBLIOGRÁFICAS}

ALLAIN, C. C.; POON, L. S.; CHAN, C. S. et al. Enzimatic determination of total serum cholesterol. Clinical Chemistry, v. 20, n. 4, p. 470-475, 1974.

AL-OTHMAN, A. A.; SHAGRAWI, R. A.; HEWEDY, F. M. et al. Plasma total, lipoprotein cholesterol, organs cholesterol and growth performance in rats fed dietary gum arabic. Food Chemistry, v.62, n. 1, p. 69-72, 1998.

AL-SHOSHAN, A. A. Study of the regular diet of selected hospitals of Ministry of Health in Saudi Arabia: intake of fatty acids, cholesterol and fiber. The Indian Journal Nutrition Dietetic, v. 29, p. 126-131, 1992.

ALVARADO, M.; DELAHAYE, E. P.; SCHNELL, M. et al. Fibra dietética en el residuo industrial del tomate y su efecto sobre la respuesta glicémica y el colesterol sérico en ratas. Archivos Latinoamericanos de Nutricion, v. 49, n. 2, p. 138-142, 1999.

ALVES, D. C.; GERUDE, M. Insuficiência coronariana. In: AUGUSTO, A. L. P.; ALVES, D. C.; MANNARINO, I. C. et al. Terapia nutricional. São Paulo: Atheneu, 1995. cap. 9, p.76-80.

ANDERSON, J. W. Dietary fiber, lipids and atherosclerosis. American Journal Cardiovascular, v. 60, p. 17-22, 1987.

ANDERSON, J. W.; TIETYEN-CLARCK, J. Dietary fibre: hyperlipidemia, hypertension and coronary heart disease. American Journal Gastroenterology, v. 81, p. $907-919,1986$

ANDERSON, J. W.; DEAKINS, D. A. ; BRIDGES, S. R. Hypocholesterolemic effects and proposed mechanisms. In: KRITCHEVSKY, D.; BONFIELD, C.; ANDERSON, J. W. Dietary fiber: chemistry, physiology, and health effects. New York: Plenum Press, 1990a. cap. 25,p. 339-363.

ANDERSON, J. W.; DEAKINS, D. A.; FLOORE, T. L. et al. Dietary fiber and coronary heart disease. Food Science and Nutrition, v. 29, n. 2, p. 95-147, 1990b. 
ANDERSON, J. W.; JONES, A. E.; MASON-RIDDELL, S. Ten different dietary fibers have significantly different effects on serun and liver lipids of cholesterol - fed rats. The Journal of Nutrition, v. 124, n. 1, p. 78-83, 1994.

ANDERSON, J. W.; STORY, L.; SIELING, B. et al. Hipocholesterolemic effect of oat bran or bean intake for hipercholesterolemic men. American Journal Clinical Nutrition, v. 40, p. 1146-1155, 1984.

ANDERSON, L.; $\quad$ DIBBLE, M. V.; $\quad$ TURKKI, P. R. et al. Nutrição. 17. ed. Rio de Janeiro: Ed Guanabara, 1988. 737p.

ANGELIS, R. C. de. Staple Brasilian food: impairment of the nutrient availability, but protective risk factors of cardiovascular disease. Bioavailability, v. 93, 1993.

ANUÁRIO ESTATÍSCO DO BRASIL. 1998, v.58 , p.3-24, 1998.

ARJMANDI, B. H.; CRAIG, J.; NATHANI, S. et al. Soluble dietary fiber and cholesterol influence in vivo hepatic and intestinal cholesterol biosyntesis in rats. The Journal of Nutrition, v. 122, n. 7, p. 1559-1565, 1992a.

ARJMANDI, B. H.; NATHANI, S.; REEVES, R. D. Dietary soluble fiber and cholesterol affect serum cholesterol concentration, hepatic portal venous short-chain fatty acid concentrations and fecal sterol excretion in rats. The Journal of Nutrition, v. 122, n. 2, p. 246-253, 1992b.

ARVANITAKIS, C.; STANNES, C. I.; FOLSCROFT, J. et al. Failure of bran to alter diet-induced hiperlipidaemia in the rat. Proceeding Society Experimental Biology Medical, v. 154, p. 550-552, 1977.

ASP, N. G.; JOHANSSON, C. A.; HALLMER, H. et al. Rapid enzymatic assay of insoluble and soluble dietary fiber. Journal of Agricultural and Food Chemistry, v. 31, n. 3, p. 476-482, 1983.

ASSOCIATION OF OFFICIAL ANALYTICAL CHEMISTS. Official methods of analysis association of official agriculture chemists. 12. ed. Washington, 1975. $1018 p$.

BAKER, R. A. Potential dietary benefits of citrus pectin and fiber. Food Technology, v. 48, n. 11, p.133-139, 1994 
BELL, L. H.; DECTORN, K. J.; REYNOLDS, H. et al. Cholesterol - lowering effects of soluble-fiber cereals as part of a prudent diet for patients with mild to moderate hypocholesterolemia. American Journal Clinical Nutrition, v. 52, n. 6, p. $1020-1026,1990$.

BOBEK, P.; CHORVATHVA, V. Effect of pectin on distribution in the lipoproteins of streptozotocin-diabetc rats fed cholesterol diet. Physiologia Bohemoslovaca, v. 33, p. 230-236, 1984.

BOTREL, N.; ABREU, C. M. P. Implantação de abacaxizal. Informe Agropecuário, v.11, n. 130, p. 22-26, 1985.

BRAVO, L.; SAURA-CALIXTO, F.; GÕNI, I. Effects of dietary fibre and tannin from apple pulp on the composition of feaces in rats. British Journal of Nutrition, v. 67, n.3, p. 463-473, 1992.

BRAVO, L.; ABIA, R.; SAURA-CALIXTO, F. Polyphenols as dietary fiber associated compounds. Comparative study on in vivo and in vitro properties. Journal of Agriculture Food Chemistry, v. 42, n. 7, p. 1481-1487, 1994.

CABRAL, J. R. S. Caracterização e avaliação de cultivares de abacaxi. Informe Agropecuário, v.11, n. 130, p. 14-16, 1985.

CARTER, J. W.; HARDMAN, E. W.; HEITMAN, D. W. et al. Type and amount of individual dietary fibers on serum lipid profiles, serum glucose concentration and energy intake in rats. Nutrition Research, v. 18, n. 10, p. 1743-1756, 1998.

CARVALHO, V. D. de. Utilização dos resíduos do abacaxizeiro. Informe Agropecuário, v.11, n. 130, p. 73-76, 1985.

CARVAlHO, V. D. de. ; CHALFOUN, S. M.; JUSTE, E. S. G. J. et al. Influência do estádio de desenvolvimento da planta na composição em carboidratos dos caules e folhas do abacaxizeiro. Pesquisa Agropecuária Brasileira, v. 24, n. 2, p. 247-252, 1989.

CARVALHO, V.D. de; CUNHA, G.P.A.; PAULA, M.B. et al. Teores de carboidratos no caule de algumas cultivares de abacaxi. Informe Agropecuário, v.4, n. 2, p. 197-200, 1985. 
CHEN, W. J. L.; ANDERSON, J. W.; CUMMINGS, J. H. The effects of oat bran, oat gum and pectin on lipid metabolism of cholesterol-fed rat. Nutrition Reports International, v. 24, n.6, p. 1093-1098, 1981.

CHEN, W. J. L.; ANDERSON, J. W.; JENNINGS, D. Propionate may mediate the hypocholesterolemic effects of certain soluble plant fibers in cholesterol-fed rats. Proceeding Society Experimental Biology Medical, v. 175, n. 2, p. 215-218, 1984.

COSTA, L. Efeito da época de colheita do abacaxizeiro (Ananas comosus L. Smooth Cayenne) nos teores de carboidratos e atividades das bromelinas do caule. Lavras, 1987. 63p. Dissertação (M. S.). Universidade Federal de Lavras.

COUTO, F.A..A. Aspectos tecnológicos da abacaxicultura mineira. Informe Agropecuário, v. 11, n. 130, p. 8-12, 1985.

CUMMINGS, J. H. Short chain fatty acids in the human colon. Gut, v. 22, p. 763-779, 1981.

CUMMINGS, J. H.; SOUTHGATE, D. A. T.; BRANCH, W. J. et al. The digestion of pectin in the human gut and its effect on calcium absorption and large bowel function. British Journal of Nutrition, v. 41, n. 3, p.477-485, 1979.

CUNHA, G. A. P.; MATOS, A. P.; CABRAL, J. R. S. et al. Abacaxi para exportação: aspectos da produção. Brasília: EMBRAPA-SPI, 1994. 41p.

DREHER, M. L. Handbook of dietary fiber. New York: Marcel Dekker, 1987. 468p.

DURRINGTON, P. N.; MANNING, A. P.; BOLTON, C. H. et al. Effect of pectin on serum lipids and lipoproteins, whole gut transit time and stool weight. Lancet, v. 2, p. 394-396, 1976.

DUTTA, S. K.; HLASKO, J. Dietary fiber in pancreatic disease: Effect of high fiber diet on fat malabsortion in pancreatic insufficiency and in vitro study of the interaction of dietary fiber with pancreatic enzymes. American Journal Clinical Nutrition, v. 41, n. 3 , p. $517-525,1985$.

ESTANISLAU, M. L. L. Aspectos econômicos da abacaxicultura. Informe Agropecuário, v. 11, n. 130, p. 3-12, 1985.

FAO. Production Yearbook. Rome, 1999. (Statisitcal Summary, 12). 
FERNANDEZ, M. L.; TREJO, A.; McNAMARA, D. J. Pectin isolated from prickly pear (Opuntia sp.) modifies low density lipoprotein metabolism in cholesterol-fed guinea pigs, The Journal of Nutrition, v. 120,n. 11, p. 1283-1290, 1990.

FIETZ, V. R. Efeitos da pectina cítrica de alta e baixa metoxilação e da celulose nos níveis séricos de colesterol e triglicerídeos em ratos hiperlipidêmicos. Piracicaba, 1998. 60p. Dissertação (Mestrado) - Escola Superior de Agricultura Luiz de Queiroz, Universidade de São Paulo.

FIETZ, V. R.; SALGADO, M. S. Efeito da pectina e da celulose nos níveis séricos de colesterol e triglicerídeos em ratos hiperlipidêmicos. Ciência e Tecnologia de Alimentos, v. 19, n. 3, p. 318-321, 1999.

FRIEDMAN, M.; FITCH, T. E.; LEVIN, C. E. et al. Feeding tomatoes to hamster reduces their plasma low-density-lipoprotein cholesterol and triglycerides. Journal of Food Science, v. 65, n. 5, p. 897-900, 2000.

FURDA, I.; BRINE, C. J., (Eds). New developments of dietary fiber. New York: Plenum Press, 1990, p. 67-82: Interactions of dietary fiber with lipids. Mechanistic theories and their limitations.

GELISSEN, I. C.; EASTWOOD, M. A. Taurocholic acid adsorption during non-starch polysaccharide fermentation: an in vitro study. British Journal of Nutrition, v. 74, n. 2, p. 221-228, 1995.

GINTER, E.; KUBEC, F. J.; VOZAR, J. et al. Natural hypocholesterolemic agent: Pectin plus ascorbic acid. International Journal for Vitamin and Nutrition Research, v.49, n. 4, p. 406-412, 1979.

GOMES, F.P. Curso de estatística experimental. 10. ed. São Paulo: Nobel, 1982. $468 \mathrm{p}$.

GORINSTEIN,S.; BARTNIKOWSKA,E.; KULASEK, G.; ZEMSER, M.; TRAKHTENBERG, S. Dietary persimmon improves lipid metabolism in rats fed diets containing cholesterol. The Journal of Nutition, v. 128, n. 11, p. 2023-2027, 1998.

GRUNDY, S. M. Cholesterol metabolism in man. Western Journal Medicine, v. 128, p. 13-25, 1978. 
GRUNDY, S. M.; DENKE, M. A. Dietary influences on serum lipids and lipoproteins. Journal of Lipids, v. 31, n. 7, p. 1149-1172, 1990.

GUNASINGHE, U. B.; GERMAN, T. L. Purification and partial characterization of virus from pineapple. Phytopathology, v. 79, n. 12, p. 1337-1341, 1989.

HAUG, A.; HOSTMARK, A. T. Lipoprotein lipases, lipoproteins and tissue lipids in rats fed fish oil or coconut oil. The Journal of Nutrition, v.117, n. 6, p. 1011-1017, 1987.

HIROCE, R.; BATAGLIA, O. C.; FURLANI, P. R. et al. Composição química inorgânica do abacaxizeiro (Ananas comosus Cayenne) da região de Bebedouro. Ciência e Cultura, v. 29, n. 3, p. 324-326, 1977.

JACKSON, K. A.; SUTER, D. A. I.; TOPPING, D. L. Oat, bran, barley and malted barley lower plasma cholesterol relative to wheat bran but differ in their effects on liver cholesterol in rats fed diets with and without cholesterol. Journal of Nutrition, v. 124, n. 9, p. 1678-1684, 1994.

JENKINS, D. J. A.; KENDALL, C. W. C.; RANSOM, T. P. P. Dietary fiber the evolution on the human diet and coronary heart disease. Nutrition Research, v. 18, n. 4, p. 633-652, 1998.

JENKINS, D. J. A.; LEEDS, A. R.; NEWTON, C. et al. Effect of pectin, guar gum and wheat fibre on serum cholesterol. Lancet, v. 1, n. 7916, p. 1116-1117, 1975.

JENKINS, D. J. A.; LEEDS, A. R.; SLAVIN, B. Guar gum in hyperlipidaemia. Lancet, v. 12, n. 7999, p. 1351, 1976.

JENKINS, D. J. A.; REYNOLDS, D.; LEEDS, A. R. et al. Hypocholesterolemic action of dietary fiber unrelated to fecal bulking effect. American Journal Clinical Nutrition, v. 32, n. 12, p. 2430-2435, 1979.

JENNINGS, C. D.; BOLEYN, K.; BRIDGES, S. R. et al. comparison of the lipid lowering and intestinal morphological effects of cholestyramine, chitosan and oat gum in rats. Proceedings of the Society for Experimental Biology and Medicine. v. 189 , p. $13-20,1988$. 
JIMENEZ-VERGARA, M.; FURR, H.; FERNANDEZ, M. L. Pectin and psyllium decrease the susceptibility of LDL to oxidation in guinea pigs. The Journal of Nutritional Biochemistry, v. 10, n. 2, p. 118-124, 1999.

JUDD, P. A.; TRUSWELL, A. S. The hypocholesterolaemic effects of pectins in rats. British Journal Nutrition, v. 53, n. 3, p. 409-425, 1985.

KAY, R. M. Effects of dietary fibre on serum lipid levels and faecal bile acid excretion. Canadian Medical Association Journal, v. 123, p. 1213-1217, 1980.

KAY, R. M.; TRUSWELL, A. S. Effect of citrus pectin on blood lipids and fecal steroid excretion in man. American Journal of Clinical Nutrition, v. 30, p. 171$175,1977$.

KOO, S. I.; STANTON, P. Effects of cellulose, pectin and guar gum on the distribution of serum cholesterol among lipoprotein fractions. Nutrition Reports International, v. 24, n. 2, p. 395-401, 1981.

KRITCHEVSKI, D. E.; STORY, J. A. Binding of bile salts in vitro by nonnutritive fiber. Journal of Nutrition, v. 104, n. 4, p. 458-462, 1974.

KRITCHEVSKY, D. E.; TEPPER, S. A.; GOODMAN, G. T. et al. Influence of oat and wheat bran on cholesterolemia in rats. Nutrition Reports International, v. 29, $\mathrm{n}$. 6, p. 1353-1359, 1984.

- KROTHIEWSKI, M. Effect of guar-gum on body-weight hunger ratings and metabolism in obese subjects. British Journal of Nutrition, v. 52, n. 1, p. 97-105, 1984.

LINSCHEER, W. G.; VERGROESEN, A. J. Lipids In: SCHILS, M. E.; OLSON, J. A.; SHIKE, M. Modern nutrition in heath and disease. 8. ed. Malvern: Léa \& Febiger, 1994. v.1.

MAHAN, L. K.; ARLIN, M. T. Krause: alimentos, nutrição e dietoterapia. 8 ed. São Paulo: Rocca, 1995. 975p.

MARLETT, J. A. Analysis of dietary fiber in human foods. In: KRITCHEVSKY, D.; BONFIELD, C.; ANDRSON, J. W. Dietary fiber: chemistry, physiology, and health effects. New York: Plenum Press, 1990. cap. 3, p. 31-48. 
MARTÍN-CARRÓN, N.; SAURA-CALIXTO, F.; GOÑI, I. Effects of dietary fibre and polyphenol-rich grape products on lipidaemia and nutritional parameters in rats. Journal of the Science of Food and Agriculture, v. 80, n. 8, p. 1183-1188, 2000.

MARZOLA, D. L.; BARTHOLOMEW, D. F. Photosynthetic patway and biomass energy production. Science, v. 250, n. 10, p. 555-559, 1975.

MATHESON, H. B.; STORY, J. A. Dietary psyllium hydrocolid and PE increase bile acid pool size and change bile acid composition in rats. The Journal of Nutrition, v. 124, n. 8, p. 1161-1165, 1994.

MATHUR, K. S.; KHAN, M. A.; SHARMA, R. D. Hypocholesterolaemic effect of Bengal gram. British Medical Journal, v. 1, n. 5583, p. 30-31, 1968.

MEDELLÍN, M. L . C.; SALDÍVAR, S. O. S.; GARZA, J. V. Efecto de la ingestión de nopal crudo e cocido (Opuntia ficus indica) en el crecimiento y perfil de colesterol total, lipoproteína y glucosa en sangre de ratas. Archivos Latinoamericanos de Nutricion, v. 48, n. 4, p. 316-323, 1998.

MEDINA, J. C.; BLEINROTH, E. W.; MARTIN, Z. J. et al. Abacaxi. Campinas: Secretária da Agricultura do Estado de São Paulo, 1978. 200p. (Frutas Tropicais, 2)

MIETTINEN, T. A.; TARPILA, S. Effect of pectin on serum cholesterol, faecal bile acids and biliary lipids in normolipidaemic and hyperlipidaemic individuals. Clinical Chimica Acta, v. 79, n. 2, p. 471-477, 1977.

MONTENEGRO, H. W. S. Abacaxi: produção, pré-processamento e transformação agroindustrial. São Paulo: Secretaria da Indústria, Comércio, Ciência e Tecnologia, 1987. 48p.

MOUNDRAS, C.; BEHR, S. R.; DEMIGNÉ, C. et al. Fermentable polysaccharides that enhance fecal bile acid excretion lower plasma cholesterol and apolipoprotein Erich HDL in rats. The Journal of Nutrition, v. 124, n. 11, p. 2179-2188, 1994.

MOUNDRAS, C.; BEHR, S. R.; RÉMESY, C.; DEMIGNÉ.; C. Fecal losses of sterols and bile acids induced by feeding rats guar gum are due to greater pool size and liver bile acid secretion. The Journal of Nutition, v. 127, n. 6, p. 1068-1076, 1997. 
NAKAMURA, H; ISHIKAWA, T.; TADA, N. et al. Effect of several kinds of dietary fibres on serum and lipoprotein lipids. Nutrition Reports International, v. 26, n. 2, p. 215-221, 1982.

NISHINA, P. M.; FREEDLAND, R. A. The effects of dietary fiber feeding on cholesterol metabolism in rats. The Journal of Nutrition, v. 120, n.7, p.800-805, 1990.

NISHINA, P. M.; SCHNEEMAN, B. O.; FREEDLAND, R. A. Effects of dietary fibers on nonfasting plasma lipoprotein and apolipoprotein levels in rats. The Journal of Nutrition, v. 121, n. 4, p. 431-437, 1991.

OLIVEIRA, H. C. F.; QUINTÃO, E. C. R. Colesterol na aterogênese. In: QUINTÃO, E. C. R. Colesterol e aterosclerose. Rio de Janeiro: Qualitymark, 1992. p. 45-49.

OLIVEIRA, M. A. de.; COUTO, F. A. A. Uso dos restos culturais do abacaxizeiro na alimentação bovina. Informe Agropecuário, v. 11, n. 130, p. 76-78, 1985.

ORGANIZAÇÃO MUNDIAL DE SAÚDE - OMS. Prevention of coronary heart disease. Geneva, 1982. 53p. (Technical Report Series, 678).

PANIANGVAIT, P.; KING, A. J.; JONES, A. D.; GERMAIN, B. G. A critical review cholesterol oxides in foods of animal origin. Journal of Food Science, v. 60, n. 6, p. $1159,1995$.

PENACHIOTTI, G. L.; ROTSTEIN, N. P.; AVELDÃNO, M. I. Effects of clofibrate on lipids and fatty acids of mouse liver. Lipids, v. 31, n. 2, p. 179-185, 1996.

PÉREZ-OLLEROS, L.; GARCÍA-CUEVAS, M.; RUIZ-ROSO, B. Influencia de la pulpa y fibra natural de algarrobas sobre algunos aspectos de la utilización nutritiva de la dieta y la colesterolemia en ratas. Food Science and Technology International, v. 5, n. 5, p. 425-430, 1999.

PIEDADE, J.; CARVALHO , V. D. de. Avaliação do potencial de aproveitamento dos resíduos do abacaxizeiro. Caracterização química do caule e folha de quatro cultivares de abacaxizeiro. In: SEMINÁRIO DE AVALIAÇÃO DO PIBIC/CNPq. 5.; CONGRESSO DE INICIAÇÃO CIENTÍFICA DA UFLA - CICESAL, 10., Lavras, 1997. Resumos. Lavras: UFLA, 1997. p. 100. 
PY, C.; LACOEVILHE, J.I.; TEISSON, C. L'ananas; sa cultura, ses produits. Paris: 1985. p. 455-458: Utilization des parties vegetatives de la plante.

REEVES, P.G.; NIELSON, F.H.; FAHEY, G. C. Jr. AIN 93 - Purified diets for laboratory rondents: final report of the American Institute of Nutrition ad hoc writing committee on the reformulation of the AIN - 76A rodent diet. The Journal of Nutrition, v. 123, n. 11, p.1939-1951, 1993.

REIS, P. R. Pragas do abacaxizeiro. Informe Agropecuário, v. 7, n. 74, p. 29-32, 1981.

REISER, S. Metabolic effects of dietary pectins related to human heath. Food Technology, v. 41, n. 2, p. 91-99, 1987.

REQUEJO, A.; RUIZ-ROSO, B.; SANJUAN, C. Method of making natural carob fiber. United States Patent. Patent number 5609905 appl. n 395413. 1997.

ROSA, C. O. B.; COSTA, N. M. B.; LEAL, P. F. G. et al. Efeito do feijão preto (Phaseolus vulgaris, L.) sem casca na redução do colesterol sanguineo de ratos hipercolesterolêmicos. Archivos Latinoamericanos de Nutricion, v. 48, n. 4, p. 299-305, 1998a.

ROSA, C. O. B.; COSTA, N. M. B.; NUMES, R. M. et al. Efeito dos feijões (Phaseolus vulgaris, L.) preto, carioquinha e vermelho na redução do colesterol sanguineo de ratos hipercolesterolêmicos. Archivos Latinoamericanos de Nutricion, v. 48, n. 4, p. 306-310, 1998b.

ROSS, J. K.; LEKLEM, J. E. The effect of dietary citrus pectin on the excretion of human fecal neutral and acid steroids and the activity of 7-alpha-dehydroxylase and beta-glucuronidase. American Journal Clinical Nutrition, v. 34, n. 10, p. 2068-2077, 1981.

RUGGIERO, C. Colheita e processamento industrial. In: SIMPÓSIO BRASILEIRO DE ABACAXICULTURA, 1., Jaboticabal, 1982. Jaboticabal: FCAUJ-UNESP, 1982. p. 279-301.

SANTOS, T. M.; SANTOS, J. E. Lipídios In: OLIVEIRA, D., SANTOS, A. C.; WILSON, E. D. Nutrição básica. São Paulo: Sarvier, 1989. p. 15-22. 
SCHNEEMAN, B. O.; CIMMARUSTI, J.; COHEN, W. et al. Composition of high density lipoproteins in rats fed various dietary fibres. The Journal of Nutrition, $v$. 114, p. 1320-1326, 1984.

SELVENDRAN, R. R.; VERNE, A. V. F. V. The chemistry and properties of plant cell walls and dietary fiber. In: KRITCHEVSKY, D.; BONFIELD, C.; ANDERSON, J. W. Dietary fiber: chemistry, physiology, anf heath effects. New York: Plenum Press, 1990. Cap. 1, p. 7-13.

SHINNICK, F. L.; INK, S. L.; MARLETT, J. A. Dose response to a dietary oat bran fraction in cholesterol - fed rats. TheJournal of Nutrition, v. 120, n. 6, p. $561-568,1990$.

SHUTLER, S. M .; LOW, A. G. Influence of baked beans on plasma lipids in pigs fed on a hypercholesterolemic diet. Proceedings of the Nutrition Society, v. 47, n. 2, p. $97,1988$.

STASSE-WOLTHIUS, M.; ALBERS, H. F. F.; Van JEVEREN, J. G. C. et al. Influence of dietary fiber from vegetables and fruits, bran or citrus pectin on serum lipids, and colonic function. American Journal Clinical Nutrition, v. 33, n. 8, p. $1745-1756,1980$.

STORY, J. A.; BALDINO, A.; CZARNECKI, S. K. et al. Modification of liver cholesterol accumulation by dietary fibre in rats. Nutrition Reports International, v. 24, n.6, p. 1213-1219, 1981.

TEBIB, K.; BITRI, L.; BESANÇON, P.; ROUANET, J. M. Polymeric grape seed tannins prevent plasma cholesterol changes in high-cholesterol-fed rats. Food Chemistry, v. 49, n. 4 , p. 403-406, 1994.

THAKUR, B. R.; SINGH, R. K.; HANDA, A. K. Chemistry and uses of pectin - a review. Critical Reviews in Food Science and Nutrition, v. 37, n. 1, p. 47-73, 1997.

TROWELL, H. Refined carbohydrate foods and fibre. In: BURKITT, D. P.; TROWELL, H. Refined carbohydrate foods and disease. London: Academic Press, 1975. p. 23-41. 
TROWELL, H.; SOUTHGATE, D. A. T.; WOLEVER, T. M. S. et al. Dietary fiber redefined. Lancet, v. 1, n. 7966, p. 967, 1976.

TRUSWELL, A. S.; KAY, R. M. Absence of effect of bran on blood lipids. Lancet, v. 1, n. 7912, p. 922-923, 1975.

TURLEY, S.; DAGGY, B.P.; DIESTCHY, J. M. Psyllium augments the cholesterol lowering action of cholestyramine in hamster by enhancing sterol loss from the liver. Gastroenterology, v. 1107, p. 444-452, 1994.

ULLRICH, I. H. Evaluation of high-fiber diet in hyperlipidemia: A review. American Journal Clinical Nutrition, v.6, n. 1, p. 19-25, 1987.

VERNY, M. A. L.; BEHR, S.; MUSTAD, V. et al. Low levels of viscous hydrocolloids lower plasma cholesterol in rats primarily by impairing cholesterol absorption. The Journal of Nutrition, v. 130, n. 2, p. 243-248, 2000.

VIGNE, J. L.; LARISON, D.; BOREL, P. et al. Effect of pectin, wheat bran and cellulose on serum lipids and lipoproteins in rats fed on a low - or high - fat diet. British Journal Nutrition, v. 58, n. 3, p. 405-413, 1987.

VUORINEN - MARKKOLA, H.; SINISALO, M.; KOIVISTO, V. A. Guar gum in inulin - dependent diabetes: effects on glycemic control and serum lipoproteins. American Journal of Clinical Nutrition, v. 56, n. 6, p. 1056-1060, 1992.

YAMADA, K.; TOKUNAGA, Y.; IKEDA, A. et al. Dietary effect of guar gum and its partially hydrolyzed product on the lipid metabolism and immune function of sprague - dawley rats. Bioscience, Biotechnology and Biochemistry, v. 63, n. 12, p. 2163-2167, 1999. 